\title{
Exploration, Celebrity, and the Making of a Transnational Hero: Fridtjof Nansen and the Fram Expedition
}

DOI:

$10.1086 / 712637$

Document Version

Accepted author manuscript

Link to publication record in Manchester Research Explorer

\section{Citation for published version (APA):}

Jones, M. (2021). Exploration, Celebrity, and the Making of a Transnational Hero: Fridtjof Nansen and the Fram Expedition. The Journal of Modern History, 93(1), 68-108. https://doi.org/10.1086/712637

\section{Published in:}

The Journal of Modern History

\section{Citing this paper}

Please note that where the full-text provided on Manchester Research Explorer is the Author Accepted Manuscript or Proof version this may differ from the final Published version. If citing, it is advised that you check and use the publisher's definitive version.

\section{General rights}

Copyright and moral rights for the publications made accessible in the Research Explorer are retained by the authors and/or other copyright owners and it is a condition of accessing publications that users recognise and abide by the legal requirements associated with these rights.

\section{Takedown policy}

If you believe that this document breaches copyright please refer to the University of Manchester's Takedown Procedures [http://man.ac.uk/04Y6Bo] or contact uml.scholarlycommunications@manchester.ac.uk providing relevant details, so we can investigate your claim.

\section{OPEN ACCESS}




\section{Exploration, Celebrity and the Making of a Transnational Hero: Fridtiof Nansen and the}

\section{Fram Expedition}

WHY did so many women and men around the world celebrate the exploits of a foreign explorer at the climax of the age of empire? The Norwegian Fridtjof Nansen's lectures about his recent Arctic expedition on board the ship Fram drew huge audiences across Europe and America in 1897 and 1898. The Royal Geographical Society (RGS) booked the Albert Hall for only the second time in its history, following Henry Morton Stanley's return from Africa in 1890 - "but even then," reported one periodical, "there was nothing like the rush for seats that there has been to hear Nansen."1 The Daily Chronicle claimed the circulation of their exclusive reports "was unprecedented $\ldots$ in the history of London journalism." ${ }^{2}$ Nansen's book about the expedition was published in at least fifteen languages, and he received honours in person from the Prince of Wales, the Presidents of France and the USA, the Habsburg Emperor, the Kaiser, and the Tsar. Following his visit to Vienna, Sigmund Freud observed that the "whole household" was now "hero-worshipping" Nansen. ${ }^{3}$ Nansen would become one of the most celebrated figures of his age, his polar exploits launching subsequent endeavours as a pioneering marine scientist, as the statesman who helped engineer Norwegian independence in 1905, and whose work with the League of Nations helped thousands after the Great War. ${ }^{4}$ He remains a leading character in general histories of polar exploration, ${ }^{5}$ and in the flourishing scholarship which has examined how Europeans, Americans and Russians worked to extend their Arctic dominions. ${ }^{6}$

The following article draws on previously unused papers from archives in Oslo and Tromsø, the journals of geographical societies, and print culture, to explain Nansen's popularity across Europe and America after Fram's return. That audiences around the world fêted Nansen following the expedition is a commonplace, but usually features only as a coda to accounts of the expedition's progress. ${ }^{7}$ While Norwegian scholars have examined the celebrations in his 
homeland, ${ }^{8}$ exactly how the expedition's story circulated outside Scandinavia and why it generated so much interest has received little attention beyond brief discussions by Robert David and Beau Riffenburgh. ${ }^{9}$ The lack of any sustained analysis of Nansen's international popularity in the late 1890s has resulted in part from some scholars' adoption of a national frame when studying the reception of expeditions. ${ }^{10}$ Such frames have proved highly productive and I do not seek to criticise the many fine works which have transformed our understanding of cultures of exploration. ${ }^{11}$ Rather I want to observe that the deployment of a national frame inevitably directs less attention to the dynamics which circulated the stories of explorers across borders. Here, I follow Michael Bravo and Sverker Sörlin in seeking to move beyond the "national claustrophobia" of much Arctic historiography. ${ }^{12}$

The adoption of a national frame has also reinforced the tendency of some scholars to explain the popularity of explorers in this period primarily with reference to their function as instruments of imperial propaganda. Berny Sèbe, for example, has argued that as the media expanded so the reputations of explorers "could be used more straightforwardly to support calls for imperial aggrandizement." ${ }^{13}$ For Edward Berenson charismatic soldiers and explorers "gave imperialism a recognizable, human face, ${ }^{14}$ while Huw Lewis-Jones believes polar explorers furnished "attractive images of resolve and heroic vitality, which could reassure the nation." ${ }^{15}$ In an important recent article Ellen Boucher argued that the enduring belief in the survival of John Franklin's crew after their disappearance expressed a "broader understanding of British racial superiority that would become so essential to the ideology of late Victorian imperialism."16 Explorers have, of course, inspired a wide range of approaches and interpretations; Michael F. Robinson, for example, has shown how scandal tarnished American polar explorers, whose hyperactive patriotism betrayed uncertainty about their place in national life. ${ }^{17}$ Even so, many accounts continue to fore-ground the ideological work performed by explorers in the service of nation and empire, particularly in the British historiography. 
Norwegian nationalists certainly lauded Nansen, while some foreign commentators claimed kinship with a white, Anglo-Saxon hero, but the power of such discourses - of appeals to imagined national, ethnic or racial communities - offers only a partial explanation of Nansen's allure. Dane Kennedy has recently noted how studies revealing the diversity of "institutions and interest groups" involved in exploration have made it "more difficult to identify a single and direct line of causation between exploration and empire."18 The following article builds on this insight to show how Nansen and the story of Fram travelled through three related networks: first, as a set of commercial products circulated through an expanding global market for commodities, print culture and media spectacle; secondly, as a set of scientific products - data, knowledge and expertise - circulated through an increasingly institutionalised network of universities, learned societies and international congresses; and, thirdly, as a set of symbolic goods projected to the public through state networks via ceremonies and monuments. ${ }^{19}$

These networks were entangled. Nineteenth-century science was made through the marketplace ${ }^{20}$ while many scholars have emphasised how states used scientific expeditions as a tool of colonization and power projection. ${ }^{21}$ But distinctions remain significant nonetheless because structures and practices differed between commercial, scientific and state networks. Assessments of profit drove the circulation of commercial products, while judgements about rank and reputation governed invitations to state occasions and scientific bodies. Here, the article follows David Harvey's injunction to distinguish between the overlapping but distinct logics of "territorial" and "capitalist imperialism."22 While states assert their interests through diplomacy, exploration and military action, economic power flows across borders in search of markets and profitability. If we interpret famous explorers primarily as instruments of propaganda, we underestimate the extent to which commercial dynamics and scientific networks propelled their stories across countries and continents. 
The circulation of Nansen's story expressed what Chris Bayly described as "the paradox of globalization": the "hardening of boundaries between nation-states and empires after 1860 led people to find ways of linking, communicating with and influencing each other across those boundaries."23 A number of historians have followed Geyer and Paulmann by drawing attention to the efflorescence of internationalism which accompanied the expansion of European empires. ${ }^{24}$ Robert Fox has analysed the "tide of scientific internationalism" which surged from the 1880 s to 1914 , expressed in the proliferation of academic periodicals, collaborative research projects, and international congresses. ${ }^{25}$ This internationalism was shaped by the competitive geopolitics of the period and persistently harnessed to the service of nation and empire. The article shows how the story of Fram straddled the dual impulses of chauvinism and cosmopolitanism generated by the rise of Science as a totem of western modernity.

By directing attention to these networks I do not seek to deny the ideological force of expedition narratives, but to deepen our understanding of the diverse messages that explorers' tales transmitted. Railways, steamships and carriages transported the story across continents, coordinated through telegraph and postal services by a cadre of intermediaries. Paying attention to the myriad exchanges facilitated by state, scientific and commercial networks de-centres the charismatic hero in the history of exploration. ${ }^{26}$ The archives foreground instead an extensive cast of brokers from business (lecture agents, publishers), the scientific community (society secretaries, university academics) and government (ministers, mayors). ${ }^{27}$

Section one briefly outlines the course of the Fram expedition. The support of the Norwegian parliament was essential, but Nansen also accessed scientific and commercial resources to fund Fram. Section two analyses how geographical societies across Europe and America showered Nansen with awards. Lavish ceremonies projected the expedition as a scientific quest in the service of humanity, but speeches and staging consistently positioned Nansen's achievement to honour the nation-state. Sections three and four reconstruct the 
commodification of the expedition, arguing that commercial motives were integral both to the organisation and meaning of the Fram expedition. While section three examines newspapers, books and advertisements, section four focuses on a neglected product, Nansen's lectures, revealing for the first time the full scale and profitability of his tours. Finally, section five examines the media coverage which accompanied this commodification, showing how newspapers and periodicals across Europe and America deployed similar textual and visual strategies to project Nansen, his wife Eva and daughter Liv through the optic of celebrity, manufacturing emotional bonds with audiences. By charting the constellation of products which circulated through entangled commercial, scientific and state networks the article highlights - and helps explain - the global reach of Nansen's story.

\section{1. "Let It Be The Norwegian Flag": The Voyage of Fram, 1893-1896}

Born in 1861, after studying in Christiania (Oslo) near his prosperous family home, Nansen worked as curator in zoology at the Bergen Museum, earning a doctorate for his groundbreaking thesis on the central nervous system. As a young man he observed how Adolf Erik Nordenskiöld had been acclaimed as a national hero in Sweden for his polar expeditions, including the first completion of the North-East Passage on SS Vega (1878-1880). ${ }^{28}$ Nansen recognised that opportunities to build a scientific career were limited by the meagre institutional resources available in Norway. ${ }^{29}$ Exploration offered a means of advancement and he began planning an expedition to Greenland which would utilise his proficiency with skis, consulting with Nordenskiöld in Stockholm. In 1888 Nansen led the first recorded crossing of Greenland with three Norwegian and two Sami companions. Although often condescending to the Sami, he developed his polar expertise by learning from the Greenland Inuit, who respected his openness to their culture. ${ }^{30}$ His Greenland success brought promotion to a post at the University of Christiania and laid the foundations for the Fram expedition. 
The origins of the expedition can be found in the new global print culture made possible by telegraphy. ${ }^{31}$ The rapid growth of mass-circulation newspapers energised exploration in the second half of the nineteenth century, as the press began to sponsor expeditions to create news. ${ }^{32}$ James Gordon Bennett Jr., owner of the New York Herald, followed the success of his despatch of Stanley to search for Dr. Livingstone by funding an Arctic expedition led by George Washington De Long. His ship the Jeanette was crushed by ice in June 1881, 400 miles from the Siberian shore. Twenty of the 33 men on board died and wreckage from the ship was found off the west coast of Greenland three years later. ${ }^{33}$ The physical geography of the Arctic remained widely debated at this time, with some proposing the North Pole lay on an undiscovered landmass while others still argued for an open polar sea. ${ }^{34}$ In the autumn of 1884 Nansen read of Professor Henrik Mohn's belief that the passage of the Jeanette's relics demonstrated that a strong ocean current flowed beneath a floating ice sheet. ${ }^{35}$ Nansen developed an audacious plan to use this current by deliberately allowing a specially-designed ship to become trapped in the ice north of Russia's New Siberian Islands. Built by Colin Archer, a Norwegian with Scottish ancestry, the rounded shape of the reinforced hull would see Fram ("Forward") raised up not crushed by the pressure of the ice. Nansen hoped the current would carry Fram over the North Pole before the ice eventually released the ship into the Greenland Sea, west of Spitzbergen.

Nansen traded the authority he had generated in Greenland to access resources from the Norwegian government and public, the international scientific community, and commercial networks, adjusting his rhetoric for different audiences. Norwegian nationalists mobilised behind his scheme in the 1890s. After fighting with the French during the Napoleonic Wars, Denmark had ceded Norway to Sweden in 1814. Norway became the junior partner in a union with Sweden, retaining a separate parliament (the Storting) and constitution, but under the sovereignty of the Swedish king and with no independent foreign service. ${ }^{36}$ State and scientific bodies honoured his exploits in Greenland, including many of the geographical societies established 
through the nineteenth century in Paris (fd. 1821), Berlin (1828), London (1830), St. Petersburg (1845), New York (1851), and Stockholm (1877), and which would number 120 by $1900 .{ }^{37}$ "It is not on the field of battle that small nations can vindicate their place in the world, and secure their independence," declared Professor Gustaf Retzius when presenting him with the Swedish Geographical Society's Vega medal. "It is in the domain of culture, of civilisation, of science and art." 38

Nansen explicitly presented Arctic exploration as a patriotic endeavour for a domestic audience. The official school-reader used in Norway from the 1890s lauded him "as a national hero" and promoted skiing as a "national Norwegian symbol." ${ }^{39}$ The organization of the Fram expedition coincided with a resurgence of nationalism focused on resentment at the Swedish monopoly of the foreign service at a time when Norway's merchant fleet had risen to be the third largest in the world. ${ }^{40}$ Speaking to the Norwegian Geographical Society which had been founded after his Greenland success, Nansen outlined the many scientific fields which would benefit from an Arctic expedition. He concluded "Let it then be Norsemen that pioneer the way! Let it be the Norwegian flag that first floats over our Pole!"41 Although 150 foreigners applied to join the expedition, ${ }^{42}$ on the insistence of the Storting Nansen selected a crew of 12 Norwegian men to reinforce the nationalist message. ${ }^{43}$ Some deputies opposed funding, but they were outvoted and the Storting eventually paid for two-thirds of the final cost of close to 450,000 Kroner (c. $£ 25,000) .{ }^{44}$ The remaining balance was met by donations from King Oscar II, wealthy individuals, public subscriptions, and scientific societies. ${ }^{45}$ Nansen actively campaigned for Norwegian independence while preparing the expedition, writing to The Times that now the issue had been "seriously taken up, it will never rest". ${ }^{46}$

Nansen deployed very different rhetoric when outlining his plans to the RGS in London. The huge expense of major expeditions constrained direct financial support, so the society's endorsement functioned more as a marker of respectability, providing access to networks of 
expertise, and status which could be traded for sponsorship. ${ }^{47}$ In place of appeals to Norwegian nationalism, Nansen emphasised how his expedition would finally solve the problem of Arctic geography by demonstrating that the North Pole lay neither on land, nor on an open sea, but on a shifting icepack. He explained that "the principal thing is to explore the unknown polar regions, not to reach exactly that mathematical point in which the axis of our globe has its northern termination." ${ }^{48}$ In this version, the conquest of the North Pole was a side-show. Many fellows praised his bravery, but most expressed strong reservations, questioning both the design of Fram and the existence of the current on which success depended. ${ }^{49}$ In spite of these doubts, the RGS still offered support; a $£ 300$ grant would enable the council to associate the society with his achievements in the unlikely event of success.

Fram sailed from Vardø in July 1893 and became trapped in the ice in October. The crew lived in relative comfort for 18 months as the ship drifted north. Although strategically omitted from his RGS lecture, the prospect of "conquering" the Pole exerted a powerful hold over Nansen's imagination. After realising that Fram would not be carried across the Pole itself, Nansen set out from the ship with Hjalmar Johansen and 28 dogs. Clive Holland later judged the decision "a crazy, reckless, foolhardy, virtually suicidal act of bravado." ${ }^{50}$ The two men calculated they had reached a new record "Farthest North" of latitude $86^{\circ} 13.6^{\prime} \mathrm{N}$ on April 7, 1895, around 230 miles from the Pole, before turning south. They would eventually trek and kayak over 700 miles, spending the winter of 1895-6 on an island in the Franz Josef Land archipelago. By astonishing good fortune, the two men were rescued when they chanced into the camp of an astonished British explorer, Frederick Jackson, on Cape Flora on June 17, 1896. They returned to Vardø on Jackson's yacht Windward on August 13, and learned a week later by cable that Fram and her crew were safe. At no point after leaving the Russian coast did the expedition encounter any indigenous peoples. 
The press's initial response was muted when London newspapers printed Reuters' telegrams from Christiania, Malmö and Vardø on Friday, August 14. The Daily Chronicle carried a half-column under the headlines "Arctic Expedition - Nansen's Return - The 'Fram' Left to Drift - Failure to Reach the Pole." Reuters interviewed an associate of Jackson who believed that "the news points, we fear, to the comparative failure of the Nansen expedition. ${ }^{51}$ The revelation that Fram had successfully returned with no lives lost, and details of Nansen's and Johansen's recordbreaking trek, swiftly changed the tenor of reports, with the outcome now presented as a triumphant vindication of the Norwegian's daring plan. ${ }^{52}$ News agencies carried the story to front pages around the world. ${ }^{53}$

Royal, civic, religious and military elites harnessed Nansen's reputation by choreographing a series of public spectacles in Norway - decorated with flags, patriotic speeches and songs. ${ }^{54}$ Nansen was re-united with his wife, and joined by the crew of Fram, which sailed south in triumph. The crowds which greeted the explorers in harbours and town squares reported extensively in the press - enabled all social classes and genders to participate in a national event. The voyage reached a climax on September 9 when a flotilla of passenger steamers and a naval squadron escorted Fram into Christiania harbour. After a tribute from the city's mayor, the party progressed to the royal palace to be welcomed by King Oscar II and Crown Prince Frederick of Denmark. Royal ceremonial followed the pattern established to honour returning explorers like Nordenskiöld, where the Swedish state, in Sörlin's words, had "lent its symbolic aura to the Arctic enterprise." ${ }^{155}$ Nansen promoted Norwegian independence both through advocacy and through his symbolic work as an embodiment of national virtue. ${ }^{56}$ The leading nationalist writer Bjørnstjerne Bjørnson told Nansen that Norwegians must free "ourselves from being psychologically and politically ruled by Sweden. Each of your deeds is a step in the right direction. ${ }^{157}$ Jacob Bull concluded his new children's book by presenting Nansen as an exemplar of Nordic masculinity. "To the youth of Norway Fridtjof Nansen's character and 
achievements stand out as a bright model, a glorious pattern for imitation." ${ }^{58}$ This propagandistic function conforms to the instrumental interpretations of explorer-heroes. But to explain Nansen's popularity around the world we must reconstruct the state, scientific and commercial networks which carried Nansen-mania beyond the borders of his homeland.

\section{2. "Soldier of Humanity": Science, Race and Nation}

The response to the Fram expedition expressed the ascendancy of Science as a totem of modernity in an age of empire. Scholars have at times dismissed the scientific claims made by famous explorers as a veneer to legitimate endeavours dedicated primarily to record-breaking adventure. ${ }^{59}$ Robert David claimed that "human interest stories dominated" Nansen's lectures and that even geographical societies offered "little more than a platform for popular heroes." 60 Michael F. Robinson has argued that polar exploration increasingly involved "manly contest rather than scientific investigation" at the end of the nineteenth century, particularly in the exploits of Robert Peary. ${ }^{61}$ Nansen's popularity complicates this story. Dramatic incidents certainly enthralled his audiences as we shall see, but scientific research remained central both to his practices and to the meanings assigned to his expeditions. Rebecca Herzig has described how projects such as the International Polar Year (1882-1883) configured the Arctic as a site of research into the laws of nature. ${ }^{62}$ Yet far from heralding the rise of the disembodied scientific observer, Herzig argues that ideas of sacrifice persisted: "knowledge of the Arctic required human suffering." ${ }^{63}$ In polar environments where fieldwork necessitated physical endurance bodies remained integral to the practices of polar science.$^{64}$ Experts policed the boundaries of legitimate research, assessing who was qualified to suffer for science according to education, class, gender and race. Explorers calibrated their projects and rhetoric to claim access both to the material resources offered by scientific institutions and symbolic capital associated with Science. 
Science shaped the story of Fram in two principal ways. First, learned societies and educational institutions circulated the empirical data and new theories generated by the expedition. Nansen consistently repeated that his principal aim had been "to explore the unknown regions that surround the Pole"65 not reach the Pole itself and many scholars have emphasised his immense contribution to the development of polar science and oceanography. ${ }^{66}$ The expedition sowed "the intellectual seeds of an ocean science revolution," demonstrating the unexpected depth of the polar sea, the remote effect of the Gulf Stream on water temperature, the primacy of wind not ocean currents as the motor of Fram's drift, and the influence of the earth's rotation. ${ }^{67}$ Scientific networks carried the expedition's findings around the world. Nansen's biographer and champion Professor W. C. Brögger launched the Fridtjof Nansen Fund for Scientific Research, which paid for the publication of Fram's results in six volumes between 1900 and 1906 by Aschehoug in Christiania, F. A. Brockhaus in Leipzig, and Longman \& Green in London, New York and Bombay. Nansen worked on the results with Vilhelm Bjerknes and Vagn Walfrid Ekman. Following the 1899 International Geographical Congress in Berlin at which he spoke, Nansen became a founding member of the International Council for the Exploration of the Sea established by 8 countries in 1902, and subsequently directed its Central Laboratory in Christiania. ${ }^{68}$ He encouraged international cooperation in the Antarctic, prompting Argentine, British, German, Norwegian, and Scottish expeditions to contribute to joint research projects, a collaboration often obscured by the "race" to the South Pole. ${ }^{69}$ General readers also displayed a considerable appetite for popular science, and many publications reported Fram's research programme in detail. ${ }^{70}$

Secondly, the invocation of Science emplotted the Fram expedition as a quest in the cause of progress which all humanity could celebrate. Sörlin's pioneering research has shown how Scandinavian countries promoted polar exploration to assert their interests in the Arctic and gain recognition on the world stage, ${ }^{71}$ "in essence a colonial programme." ${ }^{72}$ After Nansen's 
return, the Norwegian Geographical Society (NGS) proclaimed that the expedition had been a "national enterprise" which had "shown how a small nation can contribute to the great work of research and progress." ${ }^{73}$ Nansen's lecture tours revealed the Janus-face of a scientific internationalism which was consistently exploited for nationalist ends. ${ }^{74}$ Political, military and scientific elites in a succession of countries held Nansen aloft as a national trophy, exemplifying Chris Bayly's observation that "Governments called on science to legitimate themselves as often as they called on God." ${ }^{75}$

State and scientific networks honoured Nansen across Europe and America. After delivering his first lecture to the NGS on January 27,1897 , he embarked on an extensive British tour with Eva in February and March, before sailing to Europe and speaking in Paris, Berlin, Copenhagen and Stockholm. ${ }^{76}$ The couple returned to Norway where Eva gave birth to a son, Käre, before Nansen sailed alone for an extended American tour in October. ${ }^{77}$ He returned to Britain for a second tour in February 1898, and set off again with Eva across Europe from Vienna through Budapest to St Petersburg in April. ${ }^{78}$ Nansen also lectured on occasion to regional societies, but turned down numerous invitations, including from the Italian Geographical Society. ${ }^{79}$

Nansen's tours were punctuated by ceremonies which followed a strikingly similar pattern: he received both state honours and the geographical society's highest award, ${ }^{80}$ delivered a lecture hosted by the geographical society in a prominent national site, from the Trocadero in Paris to Berlin's Kroll Opera House, and was fêted by elite society at a lavish reception. ${ }^{81}$ The Prince of Wales, French President Félix Faure, Kaiser Wilhelm II, the Danish King Christian IX, Swedish King Oscar II, US President William McKinley, Habsburg Emperor Francis Joseph I, and Tsar Nicholas II all met Nansen in person. ${ }^{82}$ These events were spectacles of western modernity and state power, framing Nansen in grand halls surrounded by sumptuous costumes, with dramatic images of the Arctic projected using the latest technology. Scientific researchers 
joined central and local government elites, with leading political, military and naval figures either participating in geographical society events or staging complementary receptions. ${ }^{83}$ Honours were also awarded on occasion to Johansen, to Fram's captain Otto Sverdrup and to Sigurd Scott-Hansen, who oversaw the scientific programme, but Nansen dominated. The proliferation of awards exemplifies Samuel Clark's diagnosis of a "recognition epidemic," as different groups sought to assert their status both domestically and internationally through the distribution of honours. ${ }^{84}$

Tributes to Nansen expressed a transnational discourse of heroic exploration, where brave men endured hardship in the cause of Science and human progress. Some writers have emphasised the differences between national cultures of exploration, claiming for example that the English uniquely glorified sacrifice over efficiency. ${ }^{85}$ Sarah Pickman and Janice Cavell, among others, have challenged the explanatory value of such national stereotypes, emphasising both the diversity of expeditionary practises and the contestation of exploration discourses within national cultures. $^{86}$ Nansen's popularity across Europe and America highlights the transnational dimensions of ideas of character and heroism derived from shared classical, chivalric and religious roots. ${ }^{87}$ Introducing the Norwegian in Paris, the French Minister for Education Alfred Rambaud hailed a man who "served a great cause, an ideal soldier of humanity." 88 "Not science alone, but all humanity should be filled with gratitude to the bold explorers," declared the pioneering polar scientist Georg von Neumayer in Berlin. ${ }^{89}$ The Diploma issued by the Swedish GS stated that the expedition "had shown what science and mankind could achieve together, and expanded the horizons of our world." 90 "The work of a scholar such as Nansen," proclaimed the popular Parisian illustrated weekly Le Petit Journal, "benefits the whole universe." ${ }^{91}$ The noble cause of Science served the rhetorical function which religion and civilization performed in Africa. 
Commentators repeatedly erected Nansen's distinctive mixture of scientific expertise and physical courage as a masculine ideal. ${ }^{92}$ The President of the French Geographical Society Roland Bonaparte emphasised how Nansen combined "The insight of the man of science and the endurance of the man of action." ${ }^{93}$ In Copenhagen Economics Professor Hans William Scharling lamented that academics were rarely suited to physical labour, but happily nature had equipped Nansen both with a "great mind and at the same time with exceptional fitness." ${ }^{94}$ Welcoming Nansen to the Hungarian GS in Budapest, mathematician Dr Rezső Havass described "a respected teacher, who had braved countless dangers in the service of science." 95 Tributes singled out the same features of the expedition, highlighting the daring design and execution of Nansen's plan; the precious scientific measurements taken on board Fram, which Neumayer described as a "floating observatory"; and the explorers' powers of endurance. While Nansen and Johansen had braved the rigours of the Arctic, so Fram's successful drift had demonstrated the technological mastery of nature. The final section of the article will look more closely at the gendered dimensions of the celebrations, but here I want to note how the sexual division of the labour of exploration was reinforced by toasts to Eva, who was praised in Berlin for bearing the torment of their separation with a "bravery scarcely less admirable than the courage and endurance of her Fridtjof."196.

Presenting Fram as a romantic quest in the cause of Science facilitated these accolades. The popularity of Norse sagas, archaeological finds and research into the ethnic origins of western societies fed interest in the "old northern world" at this time. ${ }^{97}$ Tributes to Nansen mobilised a rich repertoire of historical associations, diluting any political message. Norway's

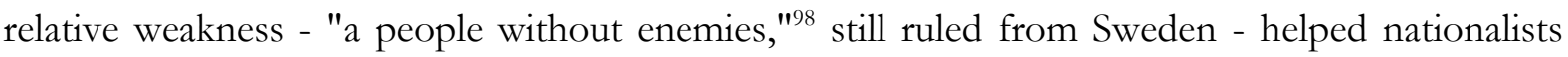
across Europe and America to view this "Modern Viking"99 with admiration rather than anxiety, a man dedicated to the peaceful cause of progress. Print culture spread the story beyond the elites who heard him in the grand halls of Europe, with many public moralists deploying Nansen 
as a moral exemplar. The Daily Chronicle reported that a number of London schools had used their Nansen editions in lessons: "what nobler example of endurance and enterprise could be placed before the youth of England?" 100 The US Elementary School Teacher later recommended third-grade children should be asked to compare the story of Columbus with accounts "of modern explorers, as [sic] Nansen, Livingstone, Stanley." ${ }^{101}$ The absence of references to religion in the atheist Nansen's pronouncements did not prevent authors seizing on his example of courage away from the battlefield. The Society for Promoting Christian Knowledge published Frederick Dolman's celebration of Nansen: The Man and His Work in Britain and the USA; the book simply ignored questions of faith. ${ }^{102}$ British writer Vera Brittain later described the Norwegian as the "hero of every school child."103

In city after city the rhetoric of internationalism was shackled in service to the nationstate. Speakers consistently positioned their own nations at the forefront of civilisation, locating the Norwegian in a lineage of their own countrymen. Rambaud paid tribute to "France, which has been joined in friendship with Norway for so many centuries, France, to whom Mr Nansen is already associated as a corresponding member of our Institute, France ... because she has given birth to a long line of intrepid explorers." 104 The military officer and President of the Austrian Geographical Society Christian von Steeb emphasised how the Austrian explorers Julius Payer and Karl Weyprecht had paved the way for Nansen, while in Berlin folklorist Professor Alfred Kirchhoff praised the crew's "Germanic willingness to suffer" and their "Germanic fearlessness and devotion to duty." ${ }^{105}$ Many British commentators hailed the warm reception of an "explorer of foreign blood" as a demonstration of their own national virtue, of "the magnanimity of an imperial world-wide people, lacking the narrow bickering animosities of races that foster the nation-caste."106 Nansen reinforced these messages, switching between English, French and German to flatter his hosts. In London he declared that "'the English nation is the nation by which I most of all could wish to be honoured or to be admired. (Cheers.)"107 In Paris he paid 
homage to the Frenchmen who had come before him, "Pasteur, the glory of humanity; De Brazza and all the French explorers who I cannot help but be inspired by." In Vienna to the Austrians: "If you follow the lead of such pioneers as Tegetthoff, Payer and Weyprecht, then you will end up in the right place!" And in St. Petersburg Nansen proclaimed that "the study of polar lands belongs first and foremost to the Russians." ${ }^{108}$ In an age of empire, internationalism was persistently riven by nationalist impulses. The International Council for the Exploration of the Sea would become a model of scientific internationalism in the $1900 \mathrm{~s},{ }^{109}$ but its participant nations still fought over the right to house its laboratories in their capital cities. ${ }^{110}$

Celebrations consistently projected the white male who combined physical prowess with exceptional intelligence as an ideal for humanity. "The best type of white manhood that I know," reflected an American writer, "is to be found far up along the Norwegian coast." ${ }^{111}$ One British commentator claimed that "Nansen is hardly to be thought a foreigner ... He is of a race whose blood we have, in a measure, ourselves." ${ }^{112}$ Such explicit discussions of race were rare, however. Negative stereotypes of Arctic indigenous peoples had circulated widely during the search for Franklin, ${ }^{113}$ but references to "Eskimo" were surprisingly infrequent. Nansen had previously condemned "the self-righteous and scandalous treatment" of "Eskimos" by Europeans whose introduction of firearms had denuded their skills and led to the "almost total extermination of reindeer." ${ }^{114}$ In an era which commonly presented the Arctic as an implacable foe, Nansen offered an early acknowledgment of the catastrophic impact of humans on the environment. ${ }^{115}$ He did not, however, repeat this critique of European imperialism in his accounts of the Fram expedition. The absence of indigenous peoples from the story of Fram perpetuated the fiction of the Arctic as an empty stage for western endeavour. ${ }^{116}$ The superiority of western civilisation was left implicit, embedded in the emphasis on science and progress which pervaded discussions of the expedition. 


\section{3. "Ride a Nansen": The Commodification of Exploration}

The modern figure of the explorer was produced by commerce: exploration necessitated writing for the market as much as travel. The following two sections reconstruct the commercial projects which operated alongside state and scientific networks to propel Nansen's image and Fram's story around the world. Nansen monetised this story in four principal ways: by selling exclusive rights to the press; through book contracts; through commercial endorsements; and through exhibitions and public lectures. David Harvey has drawn attention to the differences between "the territorial and the capitalist logics of power," overlapping but distinctive. ${ }^{117}$ Nansen served both. The Fram expedition not only promoted Norwegian independence and extended Scandinavian authority over the Arctic, but also contributed to the globalisation of print culture and urban entertainment. Newspapers, books and lectures generated vast sums, but a succession of disputes also exposed frictions in the development of capitalist imperialism in the 1890 s.

Newspapers were the primary motor of the commodification of exploration, reporting expeditions, paying for exclusives, and disseminating publicity about events and products. After James Gordon Bennett Jr. had rejected his demand for $f^{\prime 1,200}$ for the first telegram after his return, ${ }^{118}$ Nansen ran out of time to arrange an alternative and so asked his friend, the RGS librarian John Scott Keltie, to "arrange everything as you think it best; I will send all telegrams and letters to you and you will make as much as possible out of them." ${ }^{119}$ Nansen's assignment of power of attorney to Keltie expressed both the status of the RGS as an international hub for exploration, and the centrality of London to the commercial networks he sought to access. A rumour about Nansen's return helped Keltie secure a lucrative agreement. On February 13, 1896 many evening papers picked up a Reuters' cable from St. Petersburg announcing that a Siberian trader had received news that Nansen had reached the North Pole. ${ }^{120}$ The Review of Reviews noted that the report "formed one of the most sensational items of the news of the month;" 121 experts offered their opinions, while satirists made jokes. ${ }^{122}$ Prompted by this interest, the Daily Chronicle 
swiftly agreed terms with Keltie, offering $£ 1,000$ for the first telegram and a further $£ 4,000$ for the first illustrated account if Nansen had reached the pole, ${ }^{123}$ and a maximum of $f^{2,500}$ if he had not. ${ }^{124}$ In the absence of any confirmation, however, commentators expressed increasing doubts and questioned the Siberian report's veracity. ${ }^{125}$ A single false telegram had been amplified by Reuters into a global news event.

The speed with which news agencies circulated reports via the telegraph network threatened the value of the Chronicle's exclusive. The paper's managing director Frank Lloyd highlighted the "grave danger of the message being wired from Christiania to London and other parts and anticipating us in publication." ${ }^{126}$ Just as Lloyd had feared, Nansen's arrival at Vardø was widely reported in the Norwegian press on the evening of Thursday, August 13, and telegraphed around the world. The Chronicle itself was initially forced to carry Reuters' reports about the expedition, ${ }^{127}$ before finally printing Nansen's telegram in a special second edition on Saturday, August $15 .{ }^{128}$ Keltie was on holiday in the Highlands when the story broke and rushed down to placate the newspaper's disgruntled management. After threatening to void the agreement, the Chronicle eventually agreed to pay Nansen a total of $£^{2,250}$ to cover both the initial telegram and his first long article. ${ }^{129}$

The Chronicle's patience would be rewarded in one of the newspaper sensations of the nineteenth century. At the beginning of November Nansen's 15,000-word article appeared across three issues, accompanied by a full-page map and 16 illustrations "Specially Drawn From Nansen's Photographs" by one of the pioneers of photo-mechanical reproduction, Carl Hentschel. ${ }^{130}$ The Chronicle deployed innovative marketing techniques, expanding the newspaper from 10 to 12 pages, hiring special delivery carts, issuing instructions on how to bind the issues, ${ }^{131}$ and offering a postal service to deliver the three "Nansen numbers" for $4 \frac{1}{2} \mathrm{~d}$. in the UK and 6d. in "any colony or foreign country."132 Dublin's Freeman's Journal reported that sales had 
"topped all records for the London daily Press," reaching close to a quarter of a million copies each day. ${ }^{133}$

Cheap daily newspapers carried Nansen's story across social classes to the largest audience. Even so, the most lucrative commodity produced by an explorer remained the expedition leader's book. Arrangements were usually haphazard, with explorers negotiating with individual publishers in different countries; personal contacts and recommendations were crucial. For the Norwegian edition, Nansen remained with Aschehoug and William Nygaard, who had successfully published his Greenland book. The company offered an unprecedented sum of 88,000 Kroner (nearly $f^{5}, 000$ ) and were rewarded with sales of 20,000 in Norway alone. ${ }^{134}$ For the English edition, Keltie helped Nansen negotiate with Longman \& Green, Marston, Methuen, and Whittaker, before he took the largest advance on offer from Archibald Constable: ${ }^{135} \underset{£}{ } 10,000$ was viewed as a "sensational sum." ${ }^{136}$ Ben Maddison has argued that historians' preoccupation with the leaders of expeditions has obscured the labour of the ordinary seamen on whom they relied. ${ }^{137}$ His argument can be extended to employment contracts, with Johansen prohibited from publishing his own account for over a year. Renowned for its literary coverage, the Chronicle estimated that Nansen would earn $£ 25,000$ from the various editions of his book, the largest sum ever received by a polar explorer, and second only to the near $f, 50,000$ they speculated Stanley had made from In Darkest Africa (London, 1890). ${ }^{138}$ Eager to protect their investment, Constable sued the Chronicle, objecting that the newspaper's three "Nansen numbers" had breached their contract for exclusive English-language rights to Nansen's story with the exception of a single newspaper article. ${ }^{139}$ The Chronicle successfully countered that Nansen's account had been too long for one issue and that they had merely divided a single article into three parts. ${ }^{140}$

Nansen's two-volume Farthest North was published on February 8, 1897 to coincide with a British lecture tour and an exhibition at London's St. George's Gallery. ${ }^{141}$ The rush to get the 
book into print diluted Nansen's control of the text. Doubleday chose the title Farthest North and "toned down" the account of the meeting with Jackson, ${ }^{142}$ while Nansen later complained that he never had a chance to check the map and scientific data, which contained inaccuracies. ${ }^{143}$ Priced at 42 shillings, and including 120 illustrations and 16 colour plates, Farthest North was one of the most expensive books of the year. Although exact sales figures have not survived, the book was a critical and commercial smash. Typical was the review by Edward Whymper, famed for his ascent of the Matterhorn in 1865, who hailed "the most successful voyage of this century, to which no parallel can be found since the time of Columbus." ${ }^{144}$ There were occasional criticisms of the "unfortunate though necessary fate of the dogs" which Nansen and Johansen had killed and eaten, but they were not widespread. ${ }^{145}$ Constable swiftly increased their initial print run of 35,000 to 50,000. The Bookman still reported that booksellers "had been unable to obtain sufficient copies for their orders," and that a month later it was still "impossible to meet the demand," with the book topping their lists of sales in many cities, including parts of London, Birmingham, Manchester, Glasgow and Dublin. ${ }^{146}$

The circulation of Nansen's story in a multitude of editions and languages reveals the rapid expansion of print capitalism before 1900. Sales of Farthest North bear comparison with prestige expedition volumes from earlier decades; even priced at 16 shillings, Leopold McClintock's The Voyage of the Fox immediately sold out its print run of 10,000 in $1859 .{ }^{147}$ But the reproduction of photographs, formats aimed at different readerships, and foreign translations had all proliferated by the late 1890s. Publishing houses focused primarily on domestic markets demarcated by language. Nansen exploited the connections he had forged with his earlier books to sign agreements with a range of firms, including F. A. Brockhaus in Leipzig and Flammarion in Paris, alongside serialisation in the French weekly magazine L'Illustration, co-ordinated by his friend, the explorer Charles Rabot. ${ }^{148}$ Editions were published in Bohemian, Danish, Dutch, English, Finnish, French, German, Hungarian, Italian, Latvian, Norwegian, Polish, Russian, 
Spanish and Swedish. ${ }^{149}$ Constable licensed George Newnes to issue Farthest North in 20 fortnightly instalments for $6 \mathrm{~d}$, and Newnes subsequently published a two-volume edition with fewer illustrations for 8s. 6d in Britain. ${ }^{150}$ Macmillan also issued the book as part of their highly successful "Colonial Library" series for the dominions. Nansen sought an advance of $£, 5,000$ in the USA, but eventually signed with Harper and Brothers for less than he had hoped. ${ }^{151}$ Harper's Weekly published an abridged version of the Chronicle article, before a two-volume North American edition of Farthest North appeared at the end of March for $\$ 10,{ }^{152}$ later followed by a single-volume "Popular Edition" for $\$ 3 .{ }^{153}$ The Academy reported Nansen's book as the bestselling title in Pittsburgh and Toronto, and the second-highest in Boston, where demand remained strong the following year. ${ }^{154}$ While cheaper editions certainly expanded readership, bound books remained too expensive for the working classes who relied on newspapers and periodicals to learn about the expedition.

The patchy coverage and enforcement of copyright laws enabled others to profit from Nansen's story. The Berne Convention for the Protection of Literary and Artistic Works had begun to establish uniform principles for the regulation of intellectual property in $1886 .{ }^{155}$ Although extended a decade later, many countries remained outside the convention, including the USA and the Netherlands. Even though Germany was a signatory, the Chronicle's owner complained that "we cannot prevent people in Germany and elsewhere from making extracts" of their Nansen exclusives. ${ }^{156}$ The Amsterdam publisher L. J. Veen issued a Dutch translation of the Chronicle's three reports as a 96-page book, including Hentschel's illustrations without credit. ${ }^{157}$ More damagingly, the American firm A. J. Holman published two books purporting to have been written by Nansen, one in English and one in Norwegian, recycled without permission from previously published texts. ${ }^{158}$ Harpers issued a public warning and sued Holman. ${ }^{159}$ Judge Dallas initially supported Harpers' lawsuit, but Holman successfully overturned the injunction at the US Circuit Court of Appeals. ${ }^{160}$ 
The limits of Nansen's control over the commercial exploitation of his story were demonstrated by the activities of a Sheffield bookseller, James Arthur Bain, who wrote books and articles about the Norwegian ${ }^{161}$ and claimed to have lectured on the Fram expedition over 200 times. ${ }^{162}$ He travelled to Norway, named his home "Nansen House," and hoped to persuade Nansen to be his son's godfather. ${ }^{163}$ Bain engaged in cordial correspondence with Fridtjof's brother Alexander while Fram was away, but relations rapidly deteriorated after Nansen's return. Fridtjof accused him of fraudulently claiming a close friendship ${ }^{164}$ and objected to Bain's forthcoming book, which he feared would violate his own contract with Constable. ${ }^{165}$ In spite of Nansen's private opposition, Bain's biography sold well and went through a number of editions in Britain, Germany and America. ${ }^{160}$

Commercial endorsements followed a similar pattern, with Nansen unable to control the exploitation of his image. Numerous firms, particularly clothing, food and drink manufacturers, highlighted their product's performance in an extreme environment and the approval of a famous expert. Bird's Custard, Bovril, Cadbury's Cocoa, Frame Food Jelly, "Dr Jaeger's Sanatory [sic] Underwear," Mazawattee Tea, and Yost Typewriters all advertised their use on the expedition, ${ }^{167}$ while the Bjelland company even launched a "Nansen Brand" of sardines. ${ }^{168}$ The mechanisms for such endorsements appear haphazard. Some firms like the Danish margarine manufacturer Pellerin received an endorsement in return for donating products. ${ }^{169}$ The manager of Burberry unsuccessfully wrote to the RGS to ask if the society would solicit a recommendation from Nansen for their gabardine coats. ${ }^{170}$ But some companies simply used Nansen's image to promote their products without permission. Brierley Hill Cycles near Birmingham launched a "high grade" Nansen bike with the slogan "Ride A Nansen," as the firm were "very anxious to be up to date." ${ }^{171}$ Pear's Soap hadn't been used on Fram, but issued an advertisement which depicted a kilted Scotsman using Pear's having beaten Nansen to the North Pole. $^{172}$ 
The commercial exploitation of the Fram expedition expressed a particular moment in the global commodification of exploration. The unique appeal of accounts of pioneering expeditions drove innovations in newspaper and book publishing. Nansen earned significant sums, particularly from books and articles which were sold around the world in a range of languages and formats. The nascent regime of international copyright law constrained Nansen's ability to profit from this popularity, however. Constable and Harpers even petitioned Nansen to encourage King Oscar II to approach the US President "to get Norway to take the necessary steps to enjoy the full benefit of copyright in the United States." His publishers felt the intense interest in Nansen offered "a very good opportunity" to help make "the protection of Literary property as universal and secure as possible." ${ }^{173}$ Nansen's global popularity both resulted from and reinforced the spread of capitalist imperialism, facilitating the flow of economic power across continents. ${ }^{174}$

\section{4. "A Commodity of Considerable Value": Nansen's Lecture Tours, 1897-1898}

Although print cultures have been studied extensively, the lecture format has received less attention, sometimes dismissed as a residual form displaced by the rise of the press and moving pictures. ${ }^{175}$ Explorers' use of lectures to raise funds is well known, ${ }^{176}$ but scholars have only recently begun to examine the development of a global lecture industry through the late nineteenth and early twentieth centuries, driven by "lecture-brokers" with detailed knowledge of transport infrastructure, venues and audiences, who helped invigorate the format through the incorporation of new media. ${ }^{177}$ Nansen's lecture tours were far more significant than has previously been acknowledged, both hugely profitable, and helping generate and sustain his celebrity. James Redpath had established the "bureau system" in the USA in 1868 under which a central agent planned an itinerary and negotiated terms with local venues for a percentage of the profits. ${ }^{178}$ A similar system subsequently developed in Britain and it was the Lecture Agency 
which Gerald Christy took over in 1889 that came to dominate the market. ${ }^{179}$ Both Robert David and Roland Huntford claimed that the Royal Geographical Society choreographed Nansen's 1897 tour "to launch a hero on the British public"180 and drum up support for a national Antarctic expedition. ${ }^{181}$ The tour was in fact primarily a commercial venture, organised by Christy with minimal involvement from the RGS.

Just four days after news of his return, Christy offered his services to Nansen having previously organised his Greenland lectures. ${ }^{182}$ Christy initially hoped to earn "£,100 a lecture from 8 or 10 of the large towns and from $£, 50$ to $£ 100$ from another 10 to 15 towns." ${ }^{183}$ The publication of the Chronicle's Nansen numbers "greatly increased the demand," with Christy now confident of earning $£, 100$ every night for a 5-6 week tour. ${ }^{184}$ He confirmed that it was Nansen's "wish that, where possible, the arrangements be made through the local geographical societies" which had supported the expedition. Christy believed that "slightly more money might be made" by working with local agents and sharing the profits, but giving priority to the societies would be "an immense help to them" by boosting their membership. ${ }^{185}$ Even so, when he wrote to the Scottish Geographical Society Christy still stressed that Nansen "cannot lose sight of the commercial side of the question. He has a commodity of considerable value \& naturally cannot give it away altogether."186

Scientific, state and commercial networks were entwined on Nansen's lecture tours. He began his British tour in the Albert Hall on Monday, February 8, hosted by the RGS and with each fellow offered two free tickets. This lecture to a glittering array of British elites, including royalty, government ministers and foreign ambassadors, reviewed the expedition's geographical results, emphasising that the polar basin was far deeper than had previously been assumed and that Franz Josef Land was not a large landmass but a group of small islands, and offered observations on Arctic geology, animal life, and weather. ${ }^{187}$ 
Nansen delivered a very different script for the 41 further lectures which Christy arranged across Britain and Ireland between February 9 and March $24 .{ }^{188}$ Christy had sought assurance that the Norwegian would deliver a lecture of an "altogether more popular character" than that he gave to the RGS. ${ }^{189}$ In place of a summary of scientific results, Nansen presented a chronological account of the Fram's voyage "Across the Polar Region" and his journey with Johansen which highlighted the privations they had endured. He described how "the temperature was for most of the time 40 or $50 \mathrm{deg}$. below zero ... the worst was when the exhalation from our bodies was condensed in the clothes and formed into ice ... the sleeves were often so hard that they would leave wounds in the flesh at the least pressure." ${ }^{190}$ The dramatic high-points came when Nansen shot a polar bear before it could maul Johansen, and when he dived into freezing water to swim after their kayaks which had been blown away. The shooting generated "tumultuous applause" in Cheltenham, while the audience's "enthusiasm knew no bounds" after Nansen successfully retrieved the kayaks. ${ }^{191}$ An editorial in the Manchester Guardian described how the lecture had brought home the "marvels and terrors of the Arctic regions ... with extraordinary vividness." 192

Even so, Nansen's lectures continued to portray suffering as endured in the service of Science. Reports frequently described him as "Dr." Nansen, and he chose to lecture not in the furs of a frontiersman like Peary, but in jacket, tie and cloak, with this gentlemanly image reproduced on posters. ${ }^{193}$ Most British lectures were hosted by of what Charles Withers and David N. Livingstone have described as the institutions of "Civic science," which promoted "science as a public good, a unifying, moral vision under the banner of scientific and political neutrality." ${ }^{194}$ Nine of the lectures were given under the auspices of the geographical societies founded after 1884 in Scotland, Liverpool, Manchester and Tyneside, while a further 23 were hosted by a range of voluntary associations, including the Bradford Philosophical Society, Cardiff Naturalists Society and five branches of the Young Man's Christian Association, with members 
usually entitled to free tickets. Societies hired large venues and sold tickets to the public. Although focused on dramatic incidents, the popular lecture still opened and concluded by highlighting the expedition's scientific aims and principal findings. Crucially, Science underwrote Nansen's selflessness, an essential "proof of modesty" in the words of the British writer Leslie Stephen, that ruled out "the supposition which would spoil everything that he was merely going ... in the hope of becoming a lion in social circles, or to show that he was a better man than some of his predecessors." 195

Christy played a vital role negotiating with society secretaries and venues, and arranging an efficient itinerary. Concerned that newspapers would damage attendance by reprinting the lecture in full, he liaised with Constable to print a handful of copies of the popular version to gain copyright protection. ${ }^{196}$ The tour followed a standard pattern, with visits extensively reported in the local press as major civic occasions. Cheering crowds and local worthies greeted Fridtjof and Eva on arrival, usually by train. ${ }^{197}$ Ticket prices were steeply tiered, but a minimum price of a shilling enabled the respectable working classes to afford a ticket. ${ }^{198}$ The projection of visual images had invigorated the lecture format over the previous decade, ${ }^{199}$ and adverts and reports often highlighted the use of technology. ${ }^{200}$ Christy reported that "the sale of tickets for lectures was quite unprecedented."201 The "Huge Audience" at Cardiff's Park Hall prevented Nansen speaking for some time with their "thunderous applause," while "in spite of the high prices, every ticket" had been sold for Belfast's Grosvenor Hall, which was "filled to overflowing." 202 Nansen showed 27 slides to accompany his Manchester lecture, depicting Fram and the crew, the Arctic landscape, scientific research, and atmospheric effects. ${ }^{203}$ Chairmen often singled out local connections, such as the Cheltenham gunsmith who had supplied the expedition's rifles. ${ }^{204}$ Although Nansen pleaded with Christy to limit his social engagements, dinners and receptions often accompanied the lectures. 
Commercial rewards also transported Nansen around the USA. He was rumoured to have turned down an offer of 100,000 marks to lecture in Germany, ${ }^{205}$ and also declined invitations conveyed through Christy from agents to tour Australia. ${ }^{206}$ The path to America, on the other hand, was well-trodden, posed no language barriers, and promised rich rewards. Marlis Schweitzer has recently examined how North American theatre managers accelerated their search for European talent after 1893. ${ }^{207}$ Lectures formed a profitable part of the new global networks of performance culture and in late-1896 Nansen was approached by two leading US agencies. Richard Heard and George H. Hathaway, who had taken over the Redpath's agency, wanted half the profits, but guaranteed Nansen $\$ 25,000$. James B. Pond offered Nansen two thirds of the profits but gave no guarantee, instead estimating a return of $\$ 11-15,000$ and pointing to his successful arrangement of tours for Stanley and Arthur Conan Doyle, among others. ${ }^{208}$ Nansen signed for Hathaway and Heard on December 30 for an initial 50 lectures, with the "option" of a further $50 .^{209}$

Nansen's American tour followed the British template, with a grand lecture to the American Geographical Society followed by an extensive series of engagements across the country. Although opening to packed houses on the east coast at the end of October 1897, the tour took its toll: absence strained his relations with Eva, while the schedule was poorly arranged. He fell out with Hathaway and Heard over who had the authority to trigger the "option" and, after they rejected an expenses claim, Nansen pulled out of the tour altogether in January 1898. He started legal proceedings prompting Hathaway and Heard to counter-sue for breach of contract; Nansen eventually paid them $\$ 250$ to settle the suit. ${ }^{210}$ This acrimonious conclusion should not obscure Nansen's popularity in the USA. ${ }^{211}$ Pond approached Nansen again after his split from Hathaway and Heard, organising four lectures at only five days notice, which earned Nansen $\$ 1,300$. Pond pleaded with Nansen to remain in the USA. "There is quite a Nansen boom on just as you are going away ... Of all my experience never have I seen a large audience 
more intensely spellbound for two hours ... There is plenty of money in America for you." ${ }^{212}$ An elitist who viewed American culture with disdain, Nansen had already made up his mind and left New York for London on January 29, 1898.

No-one has yet noted the full scale of Nansen's second British tour in 1898, which rapidly expanded as venues clamoured for the Norwegian. ${ }^{213}$ He delivered 25 lectures between February 7 and 26, before rushing back to Norway due to the illness of his baby son. He returned in April to deliver a further 14 lectures in only 8 days between April 12 and 19, a tribute to Christy's organisational skills. ${ }^{214}$ Nansen's motivation was primarily financial. He dictated terms to Christy, explaining that "the most profitable way would be to have the lectures independent of societies on the basis of having a local manager, with sharing profits." ${ }^{215}$ His popular appeal remained undimmed and the press again reported huge attendances: Huddersfield Town Hall was "crowded in every part," while at the Edinburgh Music Hall "there was not a vacancy in the building." ${ }^{216}$ How much did Nansen make from his British lecture tours? He received no fee from either the Albert Hall or the Edinburgh lecture at which he received the Royal Scottish Geographical Society's gold medal. Four lectures at the 1,900-seat St James's Hall alone earned $£_{1,200}$ in $1897 .{ }^{217}$ Christy estimated he would continue to earn $£^{100}$ for each performance in 1898 , so an additional $f 7,500$ seems a conservative estimate from 75 British lectures. $^{218}$

The riches earned by famous explorers were so widely reported at this time that they became a regular topic for humour. The Danish newspaper Politiken began referring to "Dr. Finansen," ${ }^{119}$ while the French daily newspaper Le Gaulois expressed concern that he appeared "more enamoured of base metal than glory," before receiving reassurance about his integrity, Charles Rabot. ${ }^{220}$ "I used to think that the last place that a sensible man would wish to go to was the North Pole," observed the Yorkshire Herald. "... But I have entirely altered my mind since I have heard what an amount of money may be got by trying to get there."221 Stanley is estimated 
to have received $£ 2,000$ for a 2 -month tour in 1891 , so earnings of close to $£, 9,000$ from his British lectures alone were vast, perhaps even unprecedented. ${ }^{222}$ Lionel Clapham had asked for $£^{2} 10$ s a week to act as Nansen's full-time secretary; ${ }^{223}$ it would have taken him over 30 years to earn what Nansen made from only 28 days of lectures in 1898.

\section{5. "A Perfect Man": Print Culture and the Making of Celebrity}

The mixed media ecology of performances, print, and commercial products generated a "New Age of Celebrity" in the second half of the nineteenth century which crossed national boundaries. ${ }^{224}$ Many studies have examined how representations of polar exploration expressed particular political contexts. ${ }^{225}$ In the final part of this article I want to adopt a broader frame and use the press coverage of Nansen and his family to highlight the common features of celebrity journalism. Scholars working in media studies have emphasised that celebrity is not a "property of individuals. It is constituted discursively, by the way in which the individual is represented."226 This approach directs attention towards the representational strategies deployed by the media which operated in the realms of affect as much as ideology. From the later nineteenth century new journalistic techniques such as interviews, exclusives, and "snap-shots" purported to expose "the subject's 'real self" to public view. ${ }^{227}$ Writers and illustrators constituted public figures as objects of curiosity, admiration, desire, and ridicule, generating affective bonds with audiences which drew on normative attitudes to gender and sexuality. Across Europe and America the press projected explorers, soldiers, writers, politicians and performers alike through the optic of celebrity, nourishing the desire to see, hear and read about public figures.

Writers and illustrators used established tropes to mould Nansen's story into a variety of generic forms. Press coverage of expeditions followed a well-worn template by the $1890 \mathrm{~s} .{ }^{228}$ Reports of Fram highlighted the boldness of Nansen's plan and the drama of his trek with Johansen, repeating formulaic descriptions of brave men enduring hardship amidst the Arctic 
ice. The deployment of familiar tropes filled gaps before more detailed accounts emerged. ${ }^{229}$ Many early reports framed Nansen's dramatic meeting with Frederick Jackson as an echo of Stanley's famous encounter with Dr Livingstone. Both the up-market weeklies the Graphic (fig. 1) and the Illustrated London News (ILN) published full-page illustrations of the meeting which mirrored the iconic image of Livingstone and Stanley. ${ }^{230}$ Composition and text positioned Nansen in a lineage of great explorers signalling the type of story that readers would encounter. A staged photograph of the meeting was widely reproduced, ${ }^{231}$ while Madame Tussaud's popular London gallery chose the encounter for a waxwork tableau. ${ }^{232}$

Publications across Europe and America consistently presented Nansen as a domesticated family man by bringing Eva and Liv to the centre of the story. Eva's accompaniment of her husband during his 1897 tour generated considerable attention, with hosts pleading for her presence at receptions. ${ }^{233}$ The French weekly L'Illustration dedicated a front-page to Fridtjof and Eva when they visited Paris, "an exotic and attractive couple from the North" (fig. 2). ${ }^{234}$ Journalists claimed to offer privileged insights into their family life, with interviews illustrated by images of Fridtjof with his wife, with his daughter, and of Eva alone. ${ }^{235}$ A typical human-interest feature from the ILN presented the Norwegian as a loving father. While trying to write his book, "Liv cannot resist the temptation to steal in, jump up on his knees and commence her prattle; and then the hero yields: he is not yet proof against such interruptions as his child's caresses."236

The "Snap-shot" offered a visual equivalent of the exclusive interview, promising viewers a glimpse of the "real" Nansens. Ryan Linkoff has emphasised how publications embraced the new halftone process in this period, allowing readers "to 'bear witness' to the lives of celebrities as they had never been able to before." ${ }^{237}$ Founded in 1861 as a cheaper off-shoot of the ILN, the weekly Penny Illustrated Paper began to print "Snap-shot" photographs of sporting and military events from 1893, at the same time as the paper began to run advertisements for "snap-shot 
photography" with the Zoka camera. ${ }^{238}$ In marked contrast to the choreographed illustration of Nansen's meeting with Jackson (fig. 1), a "Snap-shot" drawing of Fridtjof and Eva leaving the London home of their friend George Baden-Powell drew authority not from the significance of the event, but solely from the couple's celebrity (fig. 3). The crude composition, with limited shading and Eva partially obscured, produced a reality effect by suggesting the hurried sketch of an eye-witness. The drawing foreshadowed the new conventions of celebrity photojournalism. The rise of this convention is usually explained as a consequence of advances in photographic technology, but the fact that an illustrator drew such a typical example of the genre suggests demand for informal images of public figures drove this new convention as much as supply.

Writers mobilised the tropes of romantic melodrama aimed in part at a female readership. Eva was usually portrayed as a devoted wife and mother who had waited stoically for her husband, the role exemplified by Lady Jane Franklin. ${ }^{239}$ Rebecca Herzig has shown how US newspapers consistently contrasted "wifely endurance" with "the perilous work of the manly explorer", and this juxtaposition was repeated across Europe. ${ }^{240}$ Fridtjof dedicated his book "To her who christened the ship and had the courage to wait;" a photograph of the explorer sitting in his cabin on Fram beneath a drawing of Liv and Eva served as the frontispiece for volumes of the American, British, French and German editions (fig. 4), and was widely reproduced. ${ }^{241}$ "Meanwhile young Mrs. Nansen stayed alone with her little girl born sometime after the departure of her father," reported Le Petit Journal, "who has never met her and always thinks of her during his most tortuous trials." ${ }^{242}$ Eva later complained that the same platitudes were repeated again and again at receptions: "Weren't those 3 years horrible? ... You, who knew how to wait, are a far greater hero than your husband, etc. etc. It makes you sick." ${ }^{243}$ Harper's Weekly claimed Eva had pored over Fridtjof's diary after his return and found that she had been most anxious when he was in "his greatest peril. That implies a telepathic communication born of intense sympathy and solicitude." ${ }^{244}$ Profiles frequently noted her considerable talents as a skier 
and singer, but contained her achievements within the conventional model of "his gentle little wife." 245

Celebrity journalism displayed Nansen as a masculine ideal, emphasising both his physique and his erudition. Profiles of "Dr." Nansen drew on the conventions of "virtual literary tourism" by suggesting that his home offered privileged insights into his real self. ${ }^{246}$ After visiting Nansen in Lysaker near Christiania, Ethel Tweedie confided that "you never know a man at all well until you have seen him in his own home."247 Many texts reproduced photographs of the explorer in his study surrounded by books and relics. ${ }^{248}$ Reports also emphasised his physical attractiveness, noting his height and build. "He may be a shade under or a shade over six feet; but either way he is a fine fellow," reported the ILN. "His loosely knit frame betokens perfect elasticity combined with the rugged strength of some hard-wood tree." 249 Visual images complemented such descriptions. Illustrations rarely depicted him smiling, instead presenting the stern visage of a brooding romantic hero, a model of Nordic masculinity (figs. 2 \& 4). "As his photographs indicate, Dr. Nansen is a man of impressive appearance," observed Harper's Weekly, "but they cannot do more than suggest the effect produced by his heroic proportions." 250

Such reports generated a demand to encounter Nansen in the flesh. "It is fashionable to be a little weary, already, of the fuss about Nansen", observed the Academy. "The best cure is to see him, and hear him. For some obscure racial reason he appeals irresistibly."251 "I had the pleasure of shaking hands with him;" recalled one Ipswich journalist, "he has a grip like iron. I understood more of the strong personality of the man from that clasp with his right hand than from his lecture."252 Sensual descriptions presented Nansen as an object of desire. The Boston Daily Globe reported that young women formed a "majority" for Nansen's performance at the packed city Music Hall, "lingering after the lecture to gaze with manifest admiration upon ... the modern viking." 253 "He is so tall and well-made that, added to his noticeable dress, everyone turns round to look at him as he walks through the London streets," observed Ethel Tweedie. ${ }^{254}$ 
Keltie made a similar observation: "It was interesting to walk along Regent street or Piccadilly with him in his tight-fitting Jaeger costume and pork-pie hat and watch how many heads turned, not of one sex only." ${ }^{255}$ One American journalist described being entranced by his "manly beauty ... His shoulders and head and neck are so well proportioned and poised that I found myself merely staring at him with no other feeling than delight in the proportions of a perfect man."256

Newspapers and periodicals across Europe and America deployed similar textual and visual strategies to configure Fridtjof and Eva as celebrities, delineating his striking physique and juxtaposing manly courage with wifely devotion. Fridtjof's life was punctuated by affairs and at this time he was rumoured to be involved with a famous beauty, Dagmar Nicolaysen. ${ }^{257}$ I found no hints of scandal in the British press, however. Celebrity journalism constructed the explorer as a head of household, configuring normative heterosexuality within the respectable boundaries of a loving family.

\section{Conclusion}

Explorers raised flags, took measurements, and sold merchandise, serving an empire of capital in tandem with the empires of nation-states and of science. The production of commodities, principally words and images packaged in a wide range of formats, was not an adjunct to the work of expeditions; it was integral to the practices of exploration which developed in the second-half of the nineteenth century, facilitated by telegraphy and halftone printing. William H. Sewell, Jr. has observed how capitalists "work systematically to generate novelty." ${ }^{158}$ Expeditions were engines of novelty, manufacturing new visions of heroic adventure in strange lands for sale in a global marketplace. Print culture projected these visions through the optic of celebrity. By conjuring the illusion of intimacy, media coverage encouraged women and men to make emotional investments in manly explorers like Fridtjof Nansen, with his stoic wife and enchanting daughter. Although many aspects of this process were already in place when the 
survivors of the Austro-Hungarian Tegetthoff expedition reached Vienna in $1874,{ }^{259}$ the subsequent expansion of news agencies and the illustrated press, of lantern slide projection, lecture agencies and new entertainment venues, of geographical societies and scientific institutions, propelled Nansen's story further and faster in the late 1890s.

Commercial, state and scientific networks carried Nansen and the story of the Fram across national borders. ${ }^{260}$ The expedition's Arctic measurements made an immense contribution to scientific knowledge and understanding. Researchers around the world accessed the thriving network of geographical societies to distribute and debate Fram's findings, which continue to inform investigations today. ${ }^{261}$ Scientific collaboration could foster cosmopolitanism, offering a potential resource for resistance to imperial exploitation and military conflict. Yet Nansen's story also reveals how Science was continuously put to work by nation-states. The campaign for Norwegian independence drove the Fram expedition into the Arctic and Scandinavian countries systematically promoted polar expeditions to assert their status. Governments across Europe and America displayed Nansen as a trophy to dramatise their contribution to the forward march of progress. Advertisers often adopted similar strategies, associating their products with Nansen to signal their modernity. The idealisation of a white European man as the embodiment of western civilisation, a supreme combination of intellectual and physical prowess, deposited another layer in the deep sediments of discourse which excluded women and other peoples from full citizenship.

Nansen had been outraged when he discovered that the managers of his American tour had written to venues stressing it was imperative that the public believed they had to buy a ticket in order to see him. ${ }^{262}$ The machinery of a global mass media, the universalist rhetoric of scientific progress, and the desires of audiences around the world constituted by celebrity journalism made Fridtjof Nansen a transnational hero, fêted by women and men who not only 
read about his story, but also turned out in huge numbers to see, to hear and, if they were lucky, perhaps even to touch a living icon of masculinity. 


\section{Figure Legends}

Figure 1. "Rivals - Yet Friends - In The White North"

Source: Graphic, LIV (September 12, 1896): 325.

Figure 2. "L’Explorateur Fridtjof Nansen et Mme Nansen"

Source: L'Illustration, 2822 (March 27, 1897): 225.

Figure 3. "Dr. and Mrs. Nansen in Eaton Square"

Source: Penny Illustrated Paper, 72 (February 13, 1897): 104.

Figure 4. "Fridtjof Nansen"

Source: Fridtjof Nansen, In Nacht und Eis (Leipzig, 1897), II: frontispiece. 


\title{
Endnotes
}

\author{
1 Academy, 1291 (January 30, 1897): 159. \\ ${ }^{2}$ Editorial, Daily Chronicle, November 3, 1896, 7. \\ 3 Quoted in Herbert Lehmann, "Two Dreams and a Childhood Memory of Freud," Journal of the American \\ Psychoanalytic Association 14 (1966): 388-405, 388.
}

${ }_{4}$ Note, for example, Nansen: A Book of Homage, ed. J. H. Whitehouse (London, 1930). The principal Englishlanguage biography remains Roland Huntford, Nansen: The Explorer as Hero (London, 1997). The most recent major Norwegian biography is Harald Dag Jølle, Nansen: Oppdageren (Oslo, 2011).

${ }^{5}$ See, among many, Pierre Berton, The Arctic Grail: the Quest for the North-west Passage and the North Pole, 1818 - 1909 (New York, 2001), 489-497; Fergus Fleming, Ninety Degrees North: The Quest for the North Pole (London, 2001), 230-68; Farthest North: Endurance and Adventure in the Quest for the North Pole, ed. Clive Holland (London, 1994), 107-139; Mattie Lainema \& Juha Nurminen, A History of Arctic Exploration: Discovery, Adventure and Endurance at the Top of the World (London: Conway, 2009), 265-273; Charles Officer and Jake Page, A Fabulous Kingdom: The Exploration of the Arctic (2nd edn., Oxford, 2012), 124-31.

${ }^{6}$ For example, Michael Bravo, North Pole: Nature and Culture (London, 2019), 133-135, 176-177; John McCannon, $A$ History of the Arctic: Nature, Exploration and Exploitation (Oxford, 2012), 174-179; John McCannon, "Exploring and Mapping the Arctic: Histories of Discovery and Knowledge," in The Routledge Handbook of the Polar Regions, eds. Mark Nuttall, Torben R. Christensen and Martin J. Siegert (Abingdon, 2018), 19-33, esp. 25-29; Arctic Discourses, eds. Anke Ryall, Johan Schimanski, and Henning Howlid Wærp (Newcastle, 2010), esp. ch. 3.

${ }^{7}$ For example, see the books in endnote 3 and Peter Lourie, Locked in Ice: Nansen's Daring Quest for the North Pole (New York, 2019).

8 See, Into the Ice: The History of Norway and the Polar Regions, eds. Einar-Arne Driveness and Harald Dag Jølle (Oslo, 2006), esp. 105-117.

${ }_{9}^{9}$ Robert G. David, The Arctic in the British Imagination, 1818-1914 (Manchester, 2000), 73-75, 115-118, 121-123; Beau

Riffenburgh, The Myth of the Explorer: The Press, Sensationalism and Geographical Discovery (Oxford, 1994), 139-143.

${ }^{10}$ For example, David, Arctic in the British Imagination; Huw Lewis-Jones, Imagining the Arctic: Heroism, Spectacle and Polar Exploration (London, 2017); David Thomas Murphy, German Exploration of the Polar World: A History, 1870-1940 (Lincoln, NE, 2002); Michael F. Robinson, The Coldest Crucible: Arctic Exploration and American Culture (Chicago, 2006); Francis Spufford, I May Be Some Time: Ice and the English Imagination (London, 1996). Exceptions include Johan Schimanski and Ulrike Spring, "The Useless Arctic: Exploiting Nature in the Arctic in the 1870s," Nordlitt 35 (2015): 13-27, which compares cultures of exploration in Norway and the Habsburg empire.

${ }^{11}$ For example, Stephen A. Walsh, "Liberalism at High Latitudes: the Politics of Polar Exploration in the Habsburg Monarchy," Austrian History Yearbook 47 (2016): 89-106, skilfully shows how campaigners for political reform under the Habsburg Monarchy promoted polar exploration as an expression of "liberal, positivist advance" (101).

12 Michael Bravo and Sverker Sörlin, "Narrative and Practice: A Introduction," in Narrating the Arctic: A Cultural History of Nordic Scientific Practices, eds. Michael Bravo and Sverker Sörlin (Canton, MA, 2002), 3-25, 8.

13 Berny Sèbe, "The Making of British and French Legends of Exploration, 1821-1914," in Reinterpreting Exploration: The West in the World, ed. Dane Kennedy (Oxford, 2014), 109-131, 117.

${ }^{14}$ Edward Berenson, Heroes of Empire: Five Charismatic Men and the Conquest of Africa (Berkeley, 2011), 2.

15 Lewis-Jones Imagining the Arctic, 295.

${ }^{16}$ Ellen Boucher, "Arctic Mysteries and Imperial Ambitions: the Hunt for Sir John Franklin and the Victorian Culture of Survival," Journal of Modern History 90 (2018): 40-75, 47.

17 Robinson, Coldest Crucible, esp. 9-12. Also see Adriana Craciun's innovative Writing Arctic Disaster: Authorship and Exploration (Cambridge, 2016). Research on explorers' subjective experiences requires different methodologies, for example, Shane McCorstine, The Spectral Arctic: A History of Dreams and Ghosts in Polar Exploration (London, 2018).

18 Dane Kennedy, "Introduction," in Reinterpreting Exploration, 9. Also see Dane Kennedy, The Last Blank Spaces: Exploring Africa and Australia (Cambridge, Mass., 2013), 5; Felix Driver, "Geography's Empire: Histories of Geographical Knowledge," Environment and Planning D: Society and Space 10 (1992): 23-40; Stephen A. Walsh, "On Slippery Ice: Discovery, Imperium, and the Austro-Hungarian North Polar Expedition (1872-4)," in Expedition into Empire: Exploratory Journeys and the Making of the Modern World, ed. Martin Thomas (Abingdon, 2015), 148-70.

19 I use "network" here to denote an interconnected group of sites of production, distribution, exchange and consumption, which individuals competed to access and control. See Davide Rodogno, Bernhard Struck and Jakob Vogel, "Introduction," in Shaping the Transnational Sphere: Experts, Networks and Issues from the 1840s to the 1940s, ed. Davide Rodogno, Bernhard Struck and Jakob Vogel (New York, 2015), 1-20, 13-14. 
${ }^{20}$ See, among many, Aileen Fyfe and Bernard Lightman, eds., Science in the Marketplace: Nineteenth-Century Sites and Experiences (Chicago, 2007).

${ }^{21}$ For example, Science, Geopolitics and Culture in the Polar Region: Norden Beyond Borders, ed. Sverker Sörlin (Farnham, 2013). Adrian Howkins, Frozen Empires: An Environmental History of the Antarctic Peninsula (Oxford, 2017), 8-15, outlines the concepts of "environmental authority" and "environmental nationalism."

${ }^{22}$ David Harvey, The New Imperialism (Oxford, 2005), 33.

${ }^{23}$ Chris Bayly, The Birth of the Modern World, 1780-1914 (Oxford, 2004), 199.

${ }^{24}$ Martin H. Geyer and Johannes Paulmann, eds., The Mechanics of Internationalism: Culture, Society, and Politics from the 1840s to the First World War (Oxford, 2001).

25 Robert Fox, Science Without Frontiers: Cosmopolitanism and National Interests in the World of Learning, 1870-1940 (Oregon, 2016), 2. Also note Rodogno et. al., "Introduction," 8.

${ }^{26}$ Cf. Berenson, Heroic Imperialists in Africa, which foregrounds the hero as an agent of "charisma."

27 Cf. Craciun, Writing Arctic Disaster, 5, which directs attention "to the manifold social agents and contingencies involved in generating exploration and exploration writings."

${ }^{28}$ For the Swedish hero-worship of Nordenskiöld, see Aant Elzinga, "The Nordic Nations in Polar Science: Expeditions, International Polar Years and their Geopolitical Dimensions," in Science, Geopolitics and Culture, 357-391.

29 Robert Marc Friedman, "Civilization and National Honour: the Rise of Norwegian Geophysical and Cosmic Science," in Making Sense of Space: the History of Norwegian Space Activities, ed. John Peter Collett (Oslo, 1995), 3-39, 37.

${ }^{30}$ Karen Langgård, "Greenlandic Attitudes Towards Norwegians and Danes from Nansen's Icecap Crossing to the 1933 World Court Verdict in The Hague," Études/Inuit/Studies 38 (2014): 53-71. For the tension between admiration and discrimination in Nansen's writing see Peter Fjågesund, The Dream of the North: A Cultural History to 1920 (Amsterdam, 2014), 464. For the nomenclature of Arctic peoples see McCannon, History of the Arctic, 11-12.

31 See Dwayne R. Winseck and Robert M. Pike, Communication and Empire: Media, Markets and Globalization, 1860-1930 (Durham, 2007). For accounts of the Fram expedition see books in endnote 3.

32 See Riffenburgh, Myth of the Explorer.

33 See Robinson, Coldest Crucible, 86-89.

${ }^{34}$ See Michael F. Robinson, "Reconsidering the Theory of the Open Polar Sea," in Extremes: Oceanography's Adventures at the Poles, eds. Keith R. Benson and Helen M. Rozwadowski (Sagamore Beach, 2007), 15-30.

${ }^{35}$ Fridtjof Nansen, Farthest North, 2 vols. (London, 1897), 1:14.

${ }^{36}$ Karen Larsen, A History of Norway (Princeton, 1967) remains a useful overview.

${ }^{37}$ Michael Heffernan, "Learned Societies," in The Sage Handbook of Geographical Knowledge, eds. J. A. Agnew and D. N. Livingstone (Los Angeles, 2011), 111-125, 117-120.

${ }^{38}$ Quoted in W. C. Brögger and Nordahl Rolfsen, Fridtjof Nansen, 1861-1893, transl. William Archer (London, 1896), 290.

39 Dag Thorkildsen, "Norwegian National Myths and Nation Building," Kirchliche Zeitgeschichte 27 (2014): 263-276, 275.

${ }^{40}$ Larsen, History of Norway, 485-487.

41 Proceedings of the Royal Geographical Society 12 (1890): 180.

${ }^{42}$ Quoted in Brögger, Nansen, 308.

${ }^{43}$ Nansen, Farthest North, 1:78-81 listed the crew in the following order: Otto Sverdrup (ship's captain), Sigurd ScottHansen (scientific observations), Henrik Blessing (doctor), Theodore Jacobsen (1st mate), Anton Amundsen (chief engineer), Adolf Juell (steward), Lars Pettersen (2nd engineer), Frederik Hjalmar Johansen (stoker), Peter Henriksen (harpooner), Bernhard Nordahl (electrics, stoker), Ivar Mogstad (assistant), Bernt Bentzen (mate).

${ }^{44}$ See Into the Ice, 107-112.

45 Nansen, Farthest North, 1:54-57, emphasised that 95\% of funding originated in Norway.

${ }^{46}$ Fridtjof Nansen to the Editor, The Times, January 2, 1893, 14.

${ }^{47}$ For the RGS see Felix Driver, Geography Militant: Cultures of Exploration and Empire (Oxford, 2001); Max Jones, "Measuring the World: Exploration, Empire and the Reform of the Royal Geographical Society, 1874-93," in The Organization of Knowledge in Victorian Britain, ed. Martin Daunton (Oxford, 2005), 313-336.

${ }^{48}$ Fridtjof Nansen, "How Can the North Polar Region be Crossed?", Geographical Journal 1 (1893): 20 [original emphasis].

49 For example, see George Richards, "Remarks on a few points in Dr Nansen's paper of November 1892," Royal Geographical Society, London (hereafter RGS), SC 130/4/iii.

${ }^{50}$ Farthest North, ed. Holland, 111.

${ }^{51}$ Daily Chronicle, August 14, 1896, 5. Cf. Launceston Examiner (Tasmania), August 15, 1896, 8: "Failed in his Mission."

${ }^{52}$ For example, Daily Chronicle, August 15, 1896, 5 \& 6.

${ }^{53}$ For example, Herald (Los Angeles), August 15, 1896, 1, reported from the "Associated Press Special Wire."

${ }^{54}$ See Into the Ice, 105-117. 
55 Sverker Sörlin, "Rituals and Resources of Natural History: The North and the Arctic in Swedish Scientific Nationalism," in Narrating the Arctic, 73-111, 108.

56 See Fjågesund, Dream of the North, 483-485.

${ }^{57}$ Quoted in Into the Ice, 111.

${ }^{58}$ Jacob Bull, Fridtjof Nansen. A Book, for the Young, transl. Mordaunt R. Barnard (London, 1898), 132.

${ }^{59}$ For example, T. H. Baughman, Before the Heroes Came: Antarctica in the 1890s (Lincoln, 1994), x; Murphy, German Exploration, 94.

${ }^{60}$ David, Arctic in the British, 74-75.

${ }^{61}$ Michael F. Robinson, "Manliness and Exploration: the Discovery of the North Pole," Osiris 30 (2015): 89-109, 90. Cf. Robinson, Coldest Crucible, 104: by the late 1880s "science had declined as a means of justification for Arctic exploration."

${ }^{62}$ For the International Polar Year see Legacies and Change in Polar Sciences: Historical, Legal and Political Reflections on The International Polar Year, eds. Jessica M Shadian and Monica Tennberg (London, 2016).

${ }^{63}$ Rebecca Herzig, Suffering for Science: Reason and Sacrifice in Modern America (New Brunswick, 2005), 72.

64 Marionne Cronin, "Polar Horizons: Images of the Arctic in Accounts of Amundsen's Polar Aviation Expeditions," Scientia Canadensis 33 (2010): 99-120, shows how narrators adapted heroic discourses to aviation.

${ }^{65}$ Nansen, Farthest North, 1:44-45; F. Nansen, "The Furthest [sic] North," Journal of the Manchester Geographical Society 13 (1897): 47-71, 48.

${ }^{66}$ See Robert Marc Friedman, "Amundsen, Nansen, and the Question of Science: Dramatizing Historical Research on the Polar Heroic," Endeavour 35 (2011): 151-159, 152-154.

${ }^{67}$ Dallas Murphy, To Follow The Water: Exploring The Ocean To Discover Climate (London, 2008), 74.

${ }^{68}$ Helen Rozwadowski, The Sea Knows No Boundaries: A Century of Marine Science Under ICES (Seattle, 2002).

${ }^{69}$ Cornelia Lüdecke, "Scientific Collaboration in Antarctica (1901-04): A Challenge in Times of Political Rivalry," Polar Record 39 (2003): 35-48.

${ }^{70}$ For example, Hebert Ward, "Dr Nansen's Polar Expedition," English Illustrated Magazine, 151 (April 1896): 14-20.

${ }^{71}$ Sverker Sörlin, "Science, Empire, and Enlightenment: Geographies of Northern Field Science," European Review of History 13 (2006): 455-472.

${ }^{72}$ Sörlin, "Rituals and Resources," 82.

73 Christiania: "Den Norske Nordpolsexpeditionen Hjemkomst," Det Norske Geografiske Selskabs Aarbog VII (18951896): 98: "nationalt foretak," "en lille nation er ære, kan tage del i det store arbejde med forskning og fremskridt."

74 Daniel Laqua, The Age of Internationalism and Belgium, 1880-1930 (Manchester, 2013), 211, emphasises "the ambivalent yet often symbiotic relationship between internationalism, nationhood and empire."

75 Bayly, Birth of the Modern, 315.

76 Paris: "Reception du Dr. Fridtjof Nansen," Comptes Rendu des Séances de la Société De Géographie 8 (1897): 121-148; Berlin: "Festsitzung zum Empfang von Dr. Fridtjof Nansen am 3. April," Verbandlungen der Gesellschaft für Erdkunde zи Berlin XXIV (1897): 223-239; Copenhagen: "Det festlige Nansenmøde," Geografisk Tidsskrift 14 (1897-98): 2-6; Stockholm: "Sammankomsten den 24 april 1897, Vegadagen," Ymer: Svenska Sällskapet för Antropologi och Geografi 17 (1897): 173-177.

${ }_{77}$ New York: "Reception of Dr Nansen," Journal of the American Geographical Society 29 (1897): 480-484.

78 Vienna: "Festversammlung zu Ehren von Fritjof Nansen," Mitteilungen der Kaiserlich-Königlichen Geographischen Gesellschaft 41 (1898): 405-408; Budapest: Földrajæi Közlemények a Magyar Földrajæi Társaságnak 26 (1898), 277-283; St. Petersburg: "Общие собрания," Отчет Императорского Русккого георафического общества [Report of the Imperial Russian Geographical Society] 49 (1898), 45-47; also The Times, April 29, 1898, 6 and Evening Telegraph (Dundee), May 3, $1898,2$. 79 Bollettino della Società Geografica Italiana ser. 3, 10 (1897): 356.

${ }^{80}$ Jon Sörensen, Fridtjof Nansen's Saga (Oslo, 1931), 342-344, lists Nansen's honours. The list was not reproduced in the 1932 English translation.

${ }^{81}$ For each event, see endnotes above. The British press only reported the London and Paris lectures in any detail.

82 Glenn M. Stein \& Lydia I. Iarukova, "Polar Honours of the Russian Geographical Society 1845-1995," Journal of the Hakluyt Society (Dec. 2008): 8. John McCannon, Red Arctic: Polar Exploration and the Myth of the North in the Soviet Union, 1932-1939 (Oxford, 1998), 17, notes how Nansen remained Russia's favourite western explorer for his combination of courage and scientific expertise.

83 For exchanges between scientific and state networks in Scandinavian capital cities see Bravo and Sörlin, "Narrative and Practice," 12-14.

84 Samuel Clark, Distributing Status: the Evolution of State Honours in Western Europe (London, 2016), 378.

85 Roland Huntford's influential polar biographies frequently assign national stereotypes an explanatory function. In Huntford, Nansen, "Norwegians are generally slow to anger and accustomed to isolation" (206), the English nurtured a distinctive "national ethos of heroic endeavour" (379), while the "Russian" admired Nansen as he was "imbued ... with respect for the strong man" (487). Also note, Berton, Arctic Grail, 489: "Scandinavian explorers were a different breed from the hidebound British and the impetuous Americans." 
${ }^{86}$ Janice Cavell, Tracing the Connected Narrative: Arctic Exploration in British Print Culture, 1818-1860 (Toronto, 2008), 4, interrogates the influence of "essentialist assumptions" of a "dichotomy between Canadian reality and British illusion" on Arctic historiography. Sarah Pickman, "Dress, Image, and Cultural Encounter in the Heroic Age of Polar Exploration," in Expedition: Fashion from the Extreme, ed. Patricia Mears (London, 2017), 31-55, 34, challenges "the simplistic adoption/respect versus rejection/prejudice dichotomy" which some writers have established between Scandinavian and British explorers.

${ }^{87}$ For a recent study of shared languages of heroism see Extraordinary Ordinariness: Everyday Heroism in the United States, Germany, and Britain, 1800-2015, ed. Simon Wendt (Chicago, 2016).

88 "Reception du Dr. Fridtjof Nansen," 129: "la conscience de servir une grande cause, d'être un soldat de l'idéal," translated by The Times, March 27, 1897, 11.

89 "Festsitzung zum Empfang," 236: "Nicht die Wissenschaft allein, sondern die gesamte Menschheit mufs von Dankgefühl für die kühnen Forscher erfüllt sein." Murphy, German Exploration, 11 argues that "German interests were best served by internationalism" in the absence of "any serious German claim to sovereignty in the Arctic."

90 "Sammankomsten," 174: "om hvad ädel hangifvenhet für ett vetenskapligt mål och manlig kraft i förening kunna åstadkomma, har vidgat synkretsen för kunskapen om vår jord."

${ }^{91}$ Le Petit Journal, 8 (April 11, 1897), 119: "[L]e résultat des travaux d'un savant tel que Nansen comme appurtenant á l'univers tout entier."

${ }^{92}$ Walsh, "Slippery Ice," 161, identifies a similar pattern in Habsburg celebrations of the Tegetthoff expedition.

93 "Reception du Dr. Fridtjof Nansen," 137: "La sagacité de l'homme de science et la ténacité de l'homme d'action."

94 "Det festlige," 5: "med et stort Tankesnille og til samme Tid skjænket en usædvanlig Legemsdygtighed."

95 Földrajzi Közlemények, 279: "igen tisztelt Tanár úr, ki életét a tudomány érdekében száz meg száz veszélynek tette ki."

96 "Festsitzung zum Empfang," 234, 238: "schwimmendes Observatorium"; "Tapferkeit getragen, kaum minder rühmenswert als der Mut und die Ausdauer ihres Fridtjof."

${ }^{97}$ See Fjågesund, Dream of the North, 485.

${ }^{98}$ Cheltenham Chronicle, February 19, 1898, 5.

${ }^{99}$ Daily Mail, February 3, 1897, 7.

100 Daily Chronicle, November 6, 1896, 5.

101 "Outline of Work for the Year 1907-08 - Third Grade," Elementary School Teacher 7 (June 1907): 609.

102 Frederick Dolman, Dr. Nansen: The Man and His Work (London, 1897).

103 Vera Brittain, Testament of Youth (London, 1933), 559.

104 "Reception du Dr. Fridtjof Nansen," 129: "La France, que tant de siècles d'amitié unissent à la Norvège, la France, à laquelle M. Nansen appartient déjà comme membre correspondant de notre Institut, la France... car elle a enfanté une longue série d'intrépides explorateurs."

105 "Festversammlung zu Ehren," 406; "Festsitzung zum Empfang," 238: "germanischer Opferwilligkeit," "germanischer Pflichttreue und Furchtlosigkeit."

${ }_{106}$ Illustrated London News, 110 (February 20, 1897): 240. Also see Editorial, Daily Chronicle, November 4, $1897,6$.

107 The Times, February 6, 1897, 12.

108 Le Figaro, March 28, 1897, 4: "Pasteur, la gloire de l'humanité; de Brazza, et tous les explorateurs francais don't je n'ai qu'à m'inspirer"; "Festversammlung zu Ehren," 408: "Kommt man nach solchen Vorgängern, wie Tegetthoff, Payer und Weyprecht, dann kommt man zur rechten Zeit!"; Niva, 29 (April 25, 1898): 340: "Въ заключеніе онъ заявилъ, что въ дъль изсльдованія полярныхъ странъ первенство принадлежить русскимъ."

109 Antony Adler, Neptune's Laboratory: Fantasy, Fear, and Science at Sea (Cambridge, MA, 2019), 83-84.

110 See Jens Smed, "The Founding of ICES - Prelude, personalities and Politics: Stockholm (1899); Christiania (1901); Copenhagen (1902)," in "Jens Smed Archive: An ICES History Lesson," https://issuu.com/icesdk/docs/jens smed archive [accessed 2 March 2020]. Cf. Urban Wråkberg, "IPY Field Stations: Functions and Meanings," in Legacies and Change, 73-97, 93: "Internationalism seldom outweighs economic, political and national interests."

111 Poulteney Bigelow, "Foreign Notes," Harper's Weekly, XLI (March 6, 1897): 222.

112 Illustrated London News, 110 (February 13, 1897): 207.

113 See David, Arctic in the British Imagination, 99-107. Boucher, "Arctic Mysteries," 60-65 notes how the effectiveness of Inuit survival techniques undercut assumptions of British technological superiority.

${ }^{114}$ Fridtjof Nansen, Eskimo Life, transl. William Archer (2nd ed., London, 1894), 347, 338. McCannon, History of the Arctic, 180, describes "the complicated mix of condescension and admiration that informed much of the era's thinking about indigenous peoples."

${ }^{115}$ For the rise of depictions of fragile polar environments from the 1960s see Hanne Nielsen, "Brand Antarctica: Selling Representations of the South from the 'Heroic Era' to the Present," (Ph.D. diss., University of Tasmania, 
2018). Andy Bruno, The Nature of Soviet Power: An Arctic Environmental History (Cambridge, 2016) 30, contrasts "two models of engagement with the environment - as a foe to vanquish or a potential friend of development."

116 Barry Lopez's classic Arctic Dreams (London, 2014 [1986]), 358, discusses how many expedition accounts "share a disassociation with the actual landscape."

${ }^{117}$ Harvey, New Imperialism, 33.

${ }^{118}$ F. Nansen to J. S. Keltie, July 20, 1893, National Library of Norway, Oslo (hereafter NLN), "Keltie, John Scott til Nansen, Fridtjof og vice versa, 1889-1896," Brevs. 48.

${ }^{119}$ F. Nansen, Power of Attorney to J. S. Keltie, June 20, 1893, University of Tromsø University Library, Norway, Digitised Archive PA11 J. S. Keltie and F. Nansen, https://doi.org/10.18710/C8FXID (hereafter UiT), PA11_F_a_1_KeltieforNansen.

${ }^{120}$ For example, Evening Telegraph and Star and Sheffield Daily Times, February 13, 1896, 4.

121 Review of Reviews, 13 (March 1896), 230.

${ }^{122}$ For example, P. Kropotkin to The Times, February 19, 1896, 11; A. W. Greely, "Nansen's Polar Expedition," National Geographic Magazine 7 (March 1896): 98; Jugend 11 (March 1896): 1.

123 Frank Lloyd to J. S. Keltie, February 17, 1896, UiT, PA11_D_c_2_DailyCh_0010.

124 J. S. Keltie to F. Nansen, November 13, 1896, NLN, Brevs. 48. The Chronicle also negotiated subsidiary agreements with European and American newspapers.

125 The Times, April 20, 1896, 6.

${ }^{126}$ Frank Lloyd to J. S. Keltie, February 28, 1896, UiT, PA11_D_c_2_DailyCh_0013.

127 Daily Chronicle, August 14, 1896, 5 and August 15, 1896, 5.

128 Daily Chronicle, August 15, 1896, 7.

${ }^{129}$ Frank Lloyd to J. S. Keltie, November 12, 1896, UiT, PA11_D_c_2_DailyCh_0043.

130 Daily Chronicle, November 2, 1896, 2-4; November 3 1896, 3-4; November 4, 1896, 3-4.

131 Daily Chronicle, November 7, 1896, 5.

132 Daily Chronicle, November 5, 1896, 4.

${ }^{133}$ Freeman's Journal, November 4, 1896, 6.

${ }^{134}$ Henning Howlid Wærp, "Fridtjof Nansen, First Crossing of Greenland (1890): Bestseller and Scientific Report," in Arctic Discourses , 43-58, 43-45.

135 See correspondence in UiT, PA11_D_b, "Keltie - Various Publishers, 1896." Constable had established the firm with Arthur Doubleday in 1891.

136 Academy, 1291 (January 30, 1897): 155.

137 Ben Maddison, Class and Colonialism in Antarctic Exploration, 1750-1920 (London, 2015). For the focus on the "leader" also see Martin Thomas, "What Is an Expedition? An Introduction," in Expedition into Empire, 1-24, 17.

138 Daily Chronicle, November 4, 1896, 4.

139 The Sunday Times, November 1, 1896, 5.

${ }_{140}$ Lloyds Weekly News, 2815 (November 1, 1896): 1.

141 Manchester Guardian, February 11, 1897, 10.

142 A. Doubleday to F. Nansen, January 24, 1897, NLN, "Constable, Archibald \& Co. til Nansen, Fridtjof [15 dec. 1896 - 19 april 1900]," Ms. fol. 1924: 2jII [Eng utg.].

${ }^{143}$ F. Nansen to the Daily Chronicle, June 26, 1899, NLN, "Christy, Gerald til Nansen, Fridtjof, 1897-1903," Ms. Fol. 1924 2gII: [Konv. 1].

144 Edward Whymper, "Nansen's Farthest North," Leisure Hour (April 1897): 369.

145 For example, Stephen, "Nansen," 21.

146 Bookman, 11 (March 1897): 164, 185; Bookman, 12 (April 1897): 4, 23.

${ }_{147}$ Cavell, Tracing the Connected, 24-29. John Murray awarded McClintock an advance of $£ 1,000$ (292, fn.32).

148 Le Gaulois, March 5, 1897, 1.

149 Bohemian: Na Severni Tǒ̀n transl. Jiř́ Guth (Prague, 1897); Danish: Fram Over Polhavet (Kristiania, 1897); French: Vers Le Pôle transl. Chalres Rabot (Paris, 1897); Dutch: In Nacht en Ijs transl. Maurits Snellen (Leiden, 1897); Finnish: Pohjan Pimeillä Perillä transl. Teuvo Pakkala (Helsinki, 1897); German: In Nacht und Eis (Leipzig, 1897); Hungarian: Éjen És Jégen Át transl. Brózik Károly (Budapest, 1898); Italian: Fra Gbiacci e Tenebre transl. Cesare Norsa (Rome, 1897); Latvian: Dr. Fritjofa Nansena Naktì un Ledū transl. Haralds Jaegers (Rīga, 1897); Norwegian: Fram Over Polbavet (Kristiania, 1897); Polish: Podróż do Bieguna Pónnocnego transl. Stanisław Janiszewski (Warsaw, 1898); Russian: Среди Авда И Ночи transl. D. N. Anuchin (St. Petersburg, 1897); Spanish: Hacia el Polo transl. Juan Fernández (Madrid, 1900); Swedish: Fram Öfver Polarhafvet (Stockholm, 1897). Most editions included a subtitle "The Norwegian Polar Expedition, 1893-1896," and credited Otto Sverdrup for reproducing his account of Fram's voyage after Nansen left the ship. Demand in Europe was high; see for example, Murphy, German Exploration, 225 fn.67.

150 Speaker, 16 (October 2, 1897): 359; Daily Mail, April 15, 1898, 3. 
${ }^{151}$ Daily Mail, January 14, 1897, 3.

152 Harper's Weekly, XLI (February 6, 1897): 131-132, 134.

153 Harper's Weekly, XLII (May 7, 1898): 456.

154 Academy, 1307 (May 22, 1897): 551-552; Academy 1316 (July 24, 1897): 77; Academy 1344 (February 5, 1898): 159.

${ }^{155}$ For the convention and the history of copyright see Silke von Lewinksi, International Copyright Law and Policy (Oxford, 2008), especially ch. 4.

${ }^{156}$ F. Lloyd to J. S. Keltie, October 6, 1896, UiT, PA11_D_c_2_DailyCh_0039.

${ }^{157}$ Fridtjof Nansen's Poolreis Door Hemzelf Beschreven (Amsterdam, 1896).

${ }_{158}$ The "Fram" Expedition. Nansen in the Frozen North (Philadelphia, 1897) and "Fram" Ekspeditionen: Nansen I Den Frosne Verden (Chicago, 1897).

${ }^{159}$ Harper's Weekly XLI (August 28, 1897): 846; North American, October 14, 1897, 5.

160 North American, March 29, 1898, 4.

${ }^{161}$ For example, J. A. Bain, "The Nansens," Idler 9 (March 1896): 304-313; "Mrs Nansen," Strand Magazine 12 (1896), 593-596; and "A Talk with Dr. Nansen," Strand Magazine, 12 (1896): 694.

162 J. A. Bain, Life and Explorations of Fridtiof Nansen (London, 1897), 292.

163 J. A. Bain to F. Nansen, September 2, 1896, NLN, "Bain, J. Arthur til Nansen, Fridtjof og Eva," Ms fol. 1924: 14a England.

164 J. A. Bain to F. Nansen, February 25, 1897, NLN, "Bain J. Arthur til Nansen, Fridtjof," Brevs. nr. 48.

165 J. A. Bain to A. Nansen, December 3 \& 8, 1896, NLN, "Bain, J. Arthur til Nansen, Alexander," Brevs. 361.

166 Bookman, 12 (April 1897): 4. Both abridged (published by S. W. Partridge) and extended (by W. Scott) versions of Bain's biography appeared in 1897, and alongside Stanley in Two Great Explorers (by Partridge) in 1907.

167 Strand Magazine, 13 (June 1897): xxv; Illustrated London News, 110 (March 6, 1897): 335; Penny Illustrated Paper, 74 (June 25, 1898): 406; Strand Magazine, 15 (June 1898): xlvi; Harper's Weekly, XLI (October 16, 1897): 1044; HAT21_547_1_259, History of Advertising Trust, Raveningham (hereafter HAT); Morning Post, March 18, 1896, 5.

168 Into the Ice, 115.

${ }^{169}$ Brögger, Nansen, 372.

${ }^{170}$ G. H. Judd to Royal Geographical Society, February 1, 1897, RGS, CB 7/63.

171 Thos. Williams to F. Nansen, March 19, 1897, UiT, PA11_D_f_1_FleretilNansen_0013.

172 A. Doubleday to F. Nansen, January 24, 1897, NLN, Ms. fol. 1924: 2jII; Pear's Soap Advertisement (1890s), HAT, HAT21_547_7_262.

173 A. Constable to F. Nansen, 2 July 1897, NLN, Ms. fol. 1924: 2jII. For the Norwegian position on the amendment of the Berne convention see von Lewinksi, International Copyright Law, 68-69..

174 See David Harvey, Spaces of Global Capitalism: Towards a Theory of Uneven Geographical Development (London, 2006), 107.

${ }^{175}$ See Tom F. Wright, Lecturing the Atlantic: Speech, Print and an Anglo-American Commons 1830-1870 (Oxford, 2017). Philip Waller, Writers, Readers, and Reputations: Literary Life in Britain 1870-1918 (Oxford, 2006), ch. 16 is the major British exception.

${ }^{176}$ For example, Murphy, German Exploration, 35; Lewis-Jones, Imagining the Arctic, 212-218; Walsh, "Liberalism," 9598.

177 See Robert Dixon, Photography, Early Cinema, and Colonial Modernity: Frank Hurley's Synchronized Lecture Entertainments (New York, 2012); Joe Kember, "The Lecture-brokers: the Role of Impresarios and Agencies in the Global Anglophone Circuit for Lantern Lecturing, 1850-1920," Early Popular Visual Culture 17 (2019): 279-303.

178 Angela Ray, The Lyceum and Public Culture in the 19th-Century United States (East Lansing, 2005), 39-40.

${ }^{179}$ For Christy see Kember, "Lecture-brokers," 288-292. ..

180 David, Arctic in the British, 73.

${ }^{181}$ Huntford, Nansen, 364-365.

${ }_{182}$ G. Christy to F. Nansen, August 17, 1896, "Christy, Gerald til Nansen, Fridtjof, 1896," MS fol 1924: 2gII [Konv. 1].

${ }_{183}$ G. Christy to F. Nansen, September 29, 1896, NLN, Ms. fol. 1924: 2gII [Konv. 1].

${ }^{184}$ G. Christy to F. Nansen, November 11, 1896, NLN, Ms. fol. 1924: 2gII [Konv. 1].

${ }^{185}$ Christy to Nansen, September 29, 1896.

${ }^{186}$ G. Christy to Scottish Geographical Society, September 21, 1896, UiT, PA_11_D_a_6_LectureA_0001.

${ }^{187}$ F. Nansen, "Some Results of the Norwegian Arctic Expedition, 1893-96," Geographical Journal, 9 (1897): 473-505.

188 "Dr Nansen's Lecture Tour, 1897," NLN, "Varia," Ms. fol. 2381.

189 G. Christy to F. Nansen, November 27, 1896, NLN, Ms. fol. 1924: 2gII [Konv. 1].

190 Nansen, "Furthest North," 58-59.

${ }^{191}$ Cheltenham Chronicle, February 19, 1898, 5.

192 Editorial, Manchester Guardian, February 24, 1897, 7.

${ }^{193}$ For the image of Peary, Amundsen and Scott see Pickman, "Dress, Image." 
${ }^{194}$ Charles W. J. Withers and David N. Livingstone, "Thinking Geographically about Nineteenth-Century Science," in Geographies of Nineteenth-Century Science, eds. David N. Livingstone and Charles W. J. Withers (Chicago, 2011$), 7$.

195 Leslie Stephen, "Nansen," International Journal of Ethics 8 (1897): 1-22, 6.

196 G. Christy to F. Nansen, January 12, 1897, NLN, Ms. fol. 1924: 2gII [Konv. 1]. F. Nansen, Across the Polar Region. A Lecture by Dr. F. Nansen (London, 1897), 28 pages.

${ }^{197}$ For example, Dundee Courier and Argus, February 18, 1897, 5.

198 "Across the Polar Region" Poster, February 9, 1897, UiT, PA11_D_h_2_InvitOgProg_0009.

199 The RGS began collecting lantern slides in 1887. See J. S. Keltie, "Thirty Years' Work of the Royal Geographical Society," Geographical Journal, 49 (May 1917): 358.

200 Huddersfield Chronicle and West Yorkshire Advertiser, February 12, 1898, 8.

201 G. Christy to F. Nansen, January 28, 1897, NLN, Ms. fol. 1924: 2gII [Konv. 1].

202 Western Mail, March 1, 1897, 5; Belfast News-letter, March 11, 1897, 5.

203 Nansen, "Furthest North," 71.

${ }^{204}$ Cheltenham Chronicle, February 19, 1898, 5.

205 Lloyds Weekly, January 31, 1897, 6.

206 C. Petersen to G. Christy, October 30, 1896, NLN, "Ad Nansen Till Christy 10 forretiningsbreu 3.10 .1896 26.5.1897 w/sekretaren," Ms Fol. 1924 2gII.

${ }^{207}$ Marlis Schweitzer, Transatlantic Broadway: The Infrastructural Politics of Global Performance (Basingstoke, 2015).

${ }^{208}$ J. B. Pond to P. Reynolds, December 8, 1896, NLN, "Vregistrerk brev, trykksaler og documenter ang. Nansen's foredragsturne i Amerika 1896 - 1897 - 1898," MS. fol. 1924: 2gI; Alexander Nansen to G. Christy, January 2, 1897, NLN, "Korrespondence mon fra hans pub med Gerald Christy Lecture Agency, London," Ms. fol. 2381.

${ }^{209}$ Copy of contract between F. Nansen, G. Hathaway and R. Heard, December 30, 1896, "Nansen, Fridtjof till Heard, Richard," Ms. fol. 1924: 2gI [konv. 2].

${ }^{210}$ Hoffman Miller to Fisher A. Baker, 26 January 1898, NLN, MS. fol. 1924: 2gI.

${ }^{211}$ Huntford, Nansen, 375, claims Nansen earned \$14,000 (around $f, 3,000$ ). His source is unclear.

212 J. B. Pond to F. Nansen, 28 January 1898, NLN, MS. fol. 1924: 2gI.

213 The Times, 31 January 1898, 6, reported 6 to 8 planned lectures; Huntford, Nansen, 376, described "a small lecture tour in England;" Jølle, Nansen, 281-282, mentions a 2-week tour. Neither David, Arctic in the British, nor Riffenburgh, Myth of the Explorer mention the 1898 tour.

${ }^{214}$ G. Christy to F. Nansen, March 28, 1898, NLN, Ms. fol. 1924: 2gII [Konv. 1].

215 G. Christy to F. Nansen, January 13, 1898, NLN, "Nansen, Fridtjof til Christy, Gerald," Ms. fol. 2381.

${ }^{216}$ Huddersfield Chronicle and West Yorkshire Advertiser, February 12, 1898, 8; Edinburgh Evening News, February 23, 1898 , 3.

217 F. Nansen to G. Christy, February 15, 1897, NLN, "Varia," Ms. fol. 2381; St James's Hall "Statement of Receipts," 23 \& 24 March 1897, NLN, "Vregistrerte forespørsle," Ms. fol. 1924: 2gII [Konv. 2].

218 G. Christy to F. Nansen, 3 February 1898, NLN, Ms. fol. 1924: 2gII [Konv. 1]. James Pond expressed surprise at f,100 per night, "double the amount Stanley got," J. B. Pond to Paul Reynolds, 8 December 1896, NLN, MS. fol. 1924: $2 \mathrm{gI}$.

219 Quoted in Daily Mail, April 19, 1897, 7.

${ }^{220}$ Le Gaulois, March 5, 1897, 1: "plus épris du vil métal que de gloire."

221 Yorkshire Herald, November 12, 1896, 6.

222 Frank McLynn, Stanley: Dark Genius of African Exploration (London, 2004), 2:340.

223 G. Christy to F. Nansen, 28 January 1897, NLN, Ms. fol. 1924: 2gII [Konv. 1].

224 Antoine Lilti, The Invention of Celebrity transl. Lynn Jeffress (Cambridge, 2017), 257. Sharon Marcus, The Drama of Celebrity (Princeton, 2019), 71, agrees that "modern celebrity culture experienced a global growth spurt" in the 1870s and $1880 \mathrm{~s}$.

${ }^{225}$ For example, Schimanski and Spring, "Useless Arctic," 13-15, shows how celebrations of the Tegetthoff expedition as a "symbol of unity" within the Habsburg empire, differed from Norwegian tributes shaped by the "material" interests of a polar nation. Also see Walsh, "Liberalism."

226 Graeme Turner, Frances Bonner and P. David Marshall, Fame Games: The Production of Celebrity in Australia (Melbourne, 2000), 11.

${ }^{227}$ Charles L. Ponce de Leon, Self-Exposure: Human-Interest Journalism and the Emergence of Celebrity in America, 1890-1940 (Chapel Hill, 2002), 7.

228 See, among many, David, Arctic in the British, 81-99.

${ }^{229}$ Cf. Johan Schimanski and Ulrike Spring, "A Black Rectangle Labelled "Polar Night": Imagining the Arctic after the Austro-Hungarian expedition of 1872-1874," in Arctic Discourses, 19-41, 21.

230 Graphic, LIV (September 12, 1896): 325; Illustrated London News, 109 (September 12, 1896): 321. Compare with Illustrated London News, 61 (August 3, 1872): 113. 
${ }^{231}$ For example, Nansen, Farthest North, II: facing 462; L'Illustration, 2824 (April 10, 1897): 270.

232 The Times, March 31, 1897, 1.

${ }^{233}$ For example, Bow Bells, February 5, 1897, 788. Daily Mail, January 28, 1897, 5, and other papers reported that Eva had been invited to sing before Queen Victoria. The Royal Archives (RA) have no record of an invitation so it may have been a journalistic invention, Julie Crocker (RA) email to the author, February 20, 2018.

${ }^{234}$ L'Illustration, 2822 (March 27, 1897): 240: "un étrange et attirant couple du Nord."

${ }^{235}$ For example Bain, "Mrs Nansen," 593-596; Graphic, LV (February 13, 1897): 188.

236 Illustrated London News (February 6, 1897): 189. This passage was repeated almost verbatim in Harper's Weekly XLI, (March 27, 1897): 322.

${ }^{237}$ Ryan Linkoff, Public Images: Celebrity, Photojournalism and the Making of the Tabloid Press (London, 2018), 47.

238 Penny Illustrated Paper, 64 (June 17, 1893): 375; Zoka advertisement, Penny Illustrated Paper, 64 (May 6, 1893): $286 .$.

${ }^{239}$ For Jane Franklin see, among many, Cavell, Tracing the Connected, chs. 7-9; Penny Russell, "Unremitting Exertions: Sentiment and Responsibility in Jane Frankin's Correspondence (1854)," in Arctic Exploration in the Nineteenth Century, ed. Frédéric Regard (London, 2013), 115-135.

${ }^{240}$ Herzig, Suffering for Science, 81.

${ }^{241}$ For example on the front cover of L'Illustration, 2819 (March 6, 1897): 240

${ }^{242}$ Le Petit Journal, April 11, 1897, 119: "Pendant ce temps la jeune Mme Nansen est restée seule avec une petite fille née quelque temps après le depart de son père, qui ne la connait pas et toujours pense à elle au milieu de ses plus cruelles épreuves."

${ }^{243}$ Quoted in Kari Herbert, Heart of the Hero: The Remarkable Women Who Inspired the Great Polar Explorers (Glasgow, 2013), 182.

${ }^{244}$ Harper's Weekly, XLI (March 6, 1897): 223.

245 Sketch, 212 (February 17, 1897): 173. Cf. Bain, "Mrs. Nansen," 593; Pall Mall Gazette, February 3, 1897, 7.

${ }^{246}$ See Charlotte Boyce, "At Home with Tennyson: Virtual Literary Tourism and the Commodification of Celebrity in the Periodical Press," in Victorian Celebrity Culture and Tennyson's Circle, eds. Charlotte Boyce, Páraic Finnerty and Ane-Marie Millim (Basingstoke, 2013), 18-52.

${ }^{247}$ Mrs. Alec Tweedie [sic], "Dr Nansen at Home," Temple Bar, 98 (1893): 31.

${ }^{248}$ For example, Herbert Ward, "Dr Nansen at Home," English Illustrated Magazine, 158 (1896): 125; J. A. Bain, Fridtjof

Nansen: His Life and Explorations (London, 1897), 55.

${ }^{249}$ Illustrated London News, 110 (February 13, 1897): 207.

${ }^{250}$ Harper's Weekly, XLI (October 20, 1897): 1087

251 Academy, 1293 (February 13, 1897): 216

${ }^{252}$ Ipswich Journal, March 4, 1898, 4

253 Boston Daily Globe, November 5, 1897, 1. Cf. Johan Schimanski \& Ulrike Spring, "Explorers' Bodies in Arctic Mediascapes: Celebrating the Return of the Austro-Hungarian Polar Expedition in 1874," Acta Borealia, 26 (2009), 50-76, which describes how press reports adorned male heroes with a "garland of female bodies" (61).

${ }^{254}$ Ethel B. Tweedie, "A Chat with Dr. Nansen," Temple Bar, 97 (1893), 188.

255 J. S. Keltie, "Thirty years' work," 368.

256 Poulteney Bigelow, "Foreign Notes," Harper's Weekly, XLI (March 6, 1897): 222.

${ }^{257}$ Huntford, Nansen, 372.

${ }^{258}$ William H. Sewell, Jr, "The Temporalities of Capitalism," Socio-Economic Review 6 (2008): 517-537, 526 (italics in original).

${ }^{259}$ See references above to Schimanski and Spring, and Walsh.

260 While agreeing with Craciun, "What Is An Explorer?," in Expedition in Empire, 25-50, 43, that "the power of commercial authorship, visual spectacle, and costumed public performance" increasingly propelled explorers through the nineteenth century, state and scientific motors remained significant.

${ }^{261}$ For example, Nancy Bazilchuk, "Nansen's Legacy Lives On 120 Years After Polar Adventure," ScienceNordic, June 13, 2013, http://sciencenordic.com/nansen $\%$ E2\%80\%99s-legacy-lives-120-years-after-polar-adventure.

${ }^{262}$ F. Nansen to R. Heard, January 3, 1898, NLN, "Nansen, Fridtjof til Heard, Richard," Ms. fol. 1924 2gI [konv. 2]. 